
\title{
R Reserach S Suare \\ Effect of equal channel angular pressing route and temperature on the mechanical behavior of ZE41 Mg alloy
}

B.P. Chiranth

C. Siddaraju

P. Sevvel

M. Gupta

R.K. Mishra

A. Joe Ajay

Ram Prabhu ( $\nabla$ ramprabhu.t@gmail.com )

Research Article

Keywords: ECAP, ZE41 Mg alloy, Microstructure, Mechanical properties, Fractography

Posted Date: February 24th, 2021

DOI: https://doi.org/10.21203/rs.3.rs-234039/v1

License: (c) (i) This work is licensed under a Creative Commons Attribution 4.0 International License.

Read Full License 


\section{Abstract}

A commercial ZE41 Mg alloy was processed by equal channel angular pressing (ECAP) using route BC ( 90 o sample rotation after each pass) and route $C$ ( 180 o sample rotation after each pass) at 250,300 and 350 oC for up to 4 passes. Significant grain refinement from $\sim 150 \mu \mathrm{m}$ to $\sim 33 \mu \mathrm{m}$ occurred at the higher third and fourth ECAP passes. The most effective process among all routes and temperature combinations was via route $\mathrm{C}$ at $250 \mathrm{oC}$. Nearly $83 \%$ increase in yield strength, $58 \%$ increase in ultimate tensile strength, and $107 \%$ increase in fracture strain were observed after 4 ECAP passes using route $C$ at $250 \mathrm{oC}$. The increase in the strength of the alloy was attributed to grain refinement during static and dynamic recrystallization. Fractography of tensile samples showed that shallow dimples change to fine dimples at higher passes modifying the failure mode from cleavage to ductile fracture.

\section{Introduction}

The demand for lightweight as well as high strength material for aerospace and automobile industries has been increasing day by day. This has made magnesium alloys more attractive as their density is lower than aluminium and have superior damping capacity with high specific strength [1, 2]. However, pure Mg has poor formability, toughness, creep strength and high flammability that inhibit their industrial applications.

Alloying is a commonly used approach to improve the mechanical properties of magnesium. The alloying elements strengthen magnesium through various strengthening mechanisms such as solid solution strengthening and precipitation hardening [3] by secondary phase formation [1-8]. Recently, it was reported that Mg alloys containing Zn, RE (Gadolinium), and Zr exhibit superior mechanical properties when compared to pure $\mathrm{Mg}$ [9]. The addition of rare earth increases the response for agehardening $[5,6]$. Further, the presence of Zn along with R.E. helps in the formation of LPSO (long period stacking ordered) structure, which helps to increase the strength of the Mg. The presence of the LPSO structure also helps to improve ductility of the magnesium via kink mechanism, which limits microcrack propagation [10-13]. In addition, these LPSO structures prevent the hardening of the b' phase during the ageing process which helps to enhance the mechanical properties [14]. Zirconium lead to microstructural homogenization and grain refinement that increased the strength of the alloy in accordance with the HallPetch relation [15].

Considerable attention is paid to the ZE41 Mg alloy because it shows low micro-porosity, good weldability and excellent creep resistance up to $150^{\circ} \mathrm{C}$ [16]. Also, this alloy was recently employed as pressure tight structures in aerospace sand casting products [17]. However, poor ductility due to the brittle ternary phase at room temperature limits the use of the ZE41 Mg alloy in structural applications [18].

Grain refinement is one of the most effective approaches for strengthening metals and alloys. In this context, equal channel angular pressing (ECAP) is a popular approach among the various severe 
plastic deformation techniques used to produce nanostructured and ultra-fine grained (UFG) microstructure in bulk, coarse-grained materials [19-20].

Many researchers have worked on different materials and studied the influence of the process parameters during ECAP on the mechanical properties. Fan et al. [21] showed that the fracture strain of a Mg-Gd-Y-Zr alloy increased from 3.5\% to $28.6 \%$ due to texture development and distribution of second phase particles after up to 4 ECAP passes using $90^{\circ}$ channel angles. Arun et al. [22] reported that ECAP using routes $B_{C}$ and $C$ for 3 passes and using a different temperature for the second and third passes significantly improves the tensile strength and marginally improves the ductility of the AZ31B Mg alloy. The grain size was reduced from $29 \mu \mathrm{m}$ to $5 \mu \mathrm{m}$ after 3 ECAP passes. Among routes $B_{C}$ and $C$, sample processed through route $\mathrm{C}$ showed better workability. The plastic flow behavior of an AZ31B Mg alloy processed by equal channel angular extrusion using routes $A, C$ and $B_{C}$ at $200{ }^{\circ} \mathrm{C}$ for one and two passes was more texture than microstructure dependent [23]

Yan et al. [24] compared the Mg-1.2Zn-0.8Gd alloy after ECAP using route Bc for 4 passes at 380 ${ }^{\circ} \mathrm{C}$ and hot rolling at $450^{\circ} \mathrm{C}$ for a total reduction of $86 \%$. The rolled samples exhibited uniform, recrystallized $14 \mu \mathrm{m}$ grains, whereas the ECAP samples showed a bimodal grain size distribution with 21 $\mu \mathrm{m}$ and $5 \mu \mathrm{m}$ grains. The high ductility and high strain hardening rate after rolling and ECAP was attributed to easy activation of basal slip and twinning due to the non-basal texture. Gopi et al. [25] obtained a homogenous and stable microstructure by the ECAP of AM90 Mg alloy using route $B_{C}$ at 275 ${ }^{\circ} \mathrm{C}$ because of dynamic recrystallization (DRX). Also, the ECAP treated samples exhibited a $25 \%$ and $80 \%$ increase in yield strength (YS) and ultimate tensile strength (UTS), respectively. In another study, Liu et al. [26] observed significantly increased ductility and strength in a Mg- $\mathrm{Gd}-\mathrm{Nd}-\mathrm{Zn}-\mathrm{Zr}$ alloy after ECAP using route $B_{C}$ for 8 passes at $375^{\circ} \mathrm{C}$. The $72 \%$ increase in YS and nearly $20 \%$ increase in UTS was attributed to phase precipitation and grain refinement.

Yan et al. [27] showed 33\%, 31\% and 25\% increase in YS, UTS and ductility respectively of a Mg$6 Z n$ alloy after ECAP using route $B_{C}$ for 6 passes at $160^{\circ} \mathrm{C}$. However, after 2 ECAP passes, there was no change in strength, but the ductility was reduced by $33 \%$ after 6 passes. Ding et al. [18] studied the mechanical response of the ZE41 Mg alloy after ECAP with $120^{\circ}$ rotation after each pass for 6 passes at $320^{\circ} \mathrm{C}$. The strength increased to $245 \mathrm{MPa}$ after the first pass and decreased to $230 \mathrm{MPa}$ after the sixth pass. A significant change in ductility was observed only after three passes and increased to $20 \%$ after 6 passes as compared to the $8 \%$ in the untreated sample. The ECAP samples exhibited a bimodal microstructure and two types of twinning viz. and . While the as-cast samples showed intergranular fracture, the ECAP samples fractured revealing both cleavage planes and tearing ridges. But the overall size of the cleavage planes decreased with an increase in ECAP passes.

Bryła et al. [28] observed that the hardness, tensile and compression strength doubled with enhancement in ductility after ECAP of ZE41A alloy using route $B_{C}$ at $150^{\circ} \mathrm{C}$ for four passes. These 
improvements in mechanical properties were attributed to grain refinement, fragmentation and the redistribution of ternary phase particles occurring during ECAP.

Most of the aforementioned studies have investigated the mechanical response of primarily REcontaining including ZE41 Mg alloys primarily using a specific ECAP route. In this study, the effect of ECAP on the mechanical behavior of ZE41 Mg alloys at the same elevated temperatures but using two processing routes $\left(B_{C}\right.$ and $\left.C\right)$ are compared. The main focus was to determine the optimal processing route and temperature by studying the effect of ECAP temperature and processing routes on the microstructure and tensile behavior.

\section{Materials And Experiments}

\subsection{Materials}

A commercially available Mg-4.3\% Zn-1.2\% Gd-0.7\% Zr (wt.\%) ZE41 alloy (Mg Elektron Ltd., UK) in the form of a $200 \mathrm{~mm} \times 150 \mathrm{~mm} \times 150 \mathrm{~mm}$ block was used for this study. A split type die of oil heattreated EN19 steel was used for the ECAP. Each ECAP die half was comprised of two channels of $15 \mathrm{~mm}$ diameter and $110 \mathrm{~mm}$ length, which intersected at an angle of $F=120^{\circ}$ (Internal channel angle) and $Y=30^{\circ}$ (Outer radius angle). The resistance coils were placed in $8 \mathrm{~mm}$ diameter holes drilled horizontally in both the dies for heating. The split die halves were held together by using M10 TVS heat-treated bolts. Photographs of the ECAP die halves and heating system are shown in Fig. 1.

\subsection{Processing}

For the ECAP, a cylindrical sample with $15 \mathrm{~mm}$ diameter and $100 \mathrm{~mm}$ length was machined using computer numerical control (CNC) machine from the rectangular ZE41 alloy block. First, ECAP was carried out at $200^{\circ} \mathrm{C}$, but due to low ductility of ZE41 Mg alloy, the deformed samples showed surface cracks (Fig. S1). Later, ECAP was conducted at $250^{\circ} \mathrm{C}, 300^{\circ} \mathrm{C}$ and $350^{\circ} \mathrm{C}$ up to 4 passes using Route $\mathrm{B}_{\mathrm{C}}$ where the sample was rotated clockwise $90^{\circ}$ after every pass, and Route $\mathrm{C}$, where the sample was rotated clockwise $180^{\circ}$ after every pass (Fig. 2). Detailed explanation about the basic routes and their effects on the properties of the sample have been summarized in the reference [29].

For conducting ECAP at high temperatures, the ECAP die was heated to the required temperature using ten resistance coils. The temperature was controlled using a thermocouple which was placed within the die and connected to the controller (Fig. 1b). The die channels were lubricated with graphite paste to minimize the friction between the die channels and sample. After the desired temperature was attained, the sample was placed inside the die for about $15 \mathrm{~min}$. ECAP was conducted using a plunger fixed to a Universal testing machine (UTM) head at a speed of $0.25 \mathrm{~mm} / \mathrm{min}$. Based on literature [25], a total strain of 0.8 was induced in each pass.

\section{See formula 1 in the supplementary files.}




\subsection{Structural characterization}

Microstructural investigation was carried out on both as-obtained and processed samples by using a Zeiss optica/ microscope and a JEOL-JSM6380LA scanning electron microscope (SEM). Samples were cut perpendicular to the pressing direction and were ground using silicon carbide abrasive papers from 600 to 2000 grit sizes. Final polishing was performed on a cloth using a $0.25 \mu \mathrm{m}$ diamond paste. The etchant was prepared by using $100 \mathrm{ml}$ ethanol and $4 \mathrm{~g}$ picric acid. After polishing, the samples were cleaned thoroughly using distilled water and immediately dried. The etching was done by dipping the sample in the etchant for about $15 \mathrm{~s}$. Nearly 200 grains were considered to measure the grain size. Measurement of grain size was done by the linear intercept method according to ASTM E112 standard using the ImageJ software.

X-ray diffraction (XRD) analysis was carried out to identify different phases present in the as-obtained and processed samples in a diffractometer operated at $20 \mathrm{~mA}$ and $30 \mathrm{kV}$ using a Cu- $\mathrm{K}_{\mathrm{a}}$ radiation with a $\mathrm{Ni}$ filter. The angular range of $20^{\circ}$ to $90^{\circ}$ was scanned at a rate of $2 \% \mathrm{~min}$.

Energy-dispersive X-ray spectroscopy (EDX) analysis was also carried out using a JEOL-JSM6380LA SEM to determine the composition of the alloy after the various ECAP processing. Electron beam backscattered diffraction (EBSD) was carried out to study the grain orientation and volume fraction in a field emission SEM (FEI Quanta 200HV SEM with TSL-EDX OIM system) using a beam current of $10 \mathrm{nA}$ and 15 $\mathrm{kV}$. Sample surface areas of $100 \times 100 \mu \mathrm{m}$ were scanned using a step size of $0.1 \mu \mathrm{m}$. After the test, TSL OIM software was used for the analysis. Samples were prepared by mechanical grinding up to $4000 \mathrm{grit}$ $\mathrm{SiC}$ paper, and then electropolishing using $70 \%$ methanol and $30 \%$ nitric acid solution at $10 \mathrm{~V}$ for $10 \mathrm{~s}$ at $-25^{\circ} \mathrm{C}$.

\subsection{Mechanical characterization}

Samples for tensile testing were prepared according to ASTM E8 standard (Fig. 3). Tensile tests were conducted after each pass at $25^{\circ} \mathrm{C}$ at a constant speed of $0.5 \mathrm{~mm} / \mathrm{min}$ using a horizontal tensile testing machine (Electronic tensometer, $20 \mathrm{kN}$ capacity PC-2000 Bench model). After the tensile tests, the samples were preserved in vacuum desiccators to prevent oxidation. Fractography was carried out using a JEOL-JSM6380LA SEM.

Vickers microhardness tests were carried out on untreated and ECAP samples using a Matsuzawa MMT-X7A microhardness tester. Hardness test was conducted by applying a load of $25 \mathrm{~g}$ and dwell time of $15 \mathrm{~s}$. An average of three readings were obtained from different locations to avoid irregularities in the results.

\section{Results And Discussion}

\subsection{Microstructure of untreated ZE41 Mg alloy}


Optical microscopy of the untreated ZE41 Mg alloy showed that the microstructure contains primarily $150 \mu \mathrm{m}$ sized $\alpha$-Mg grains (Fig. 4). In addition, a second eutectic phase was present in a discontinuous fashion along the grain boundaries.

The addition of $\mathrm{Zn}, \mathrm{Gd}$ and $\mathrm{Zr}$ to pure $\mathrm{Mg}$ leads to the formation of this second eutectic phase along the grain boundary in the form of discontinuous islands [30,31]. Fig. 5 shows SEM images and EDX spectra obtained from different regions of the same untreated ZE41 Mg alloys. EDX analysis showed that these islands along the grain boundary are rich in $\mathrm{Zn}$ and $\mathrm{Gd}$ as compared to the Mg matrix (Fig. $5 \mathrm{~b}$ \& $\mathrm{c}$ and Table 1). This second phase could be the $\mathrm{Mg}_{3} \mathrm{Zn}_{3} \mathrm{Gd}_{2}$ W-phase observed in the as-cast ZEK620 [30] and the as-extruded Mg95.9-Zn3.5-Gd0.6 alloys [32]. The EDX spectrum did not show Zr peaks due to low concentration and/or forming a solid solution with $\mathrm{Mg}$.

Table 1 EDX analysis (at.\%) for the untreated ZE41 Mg alloy.

\begin{tabular}{|llllll|}
\hline Sample & Region & $\mathrm{Mg}$ & $\mathrm{Zn}$ & $\mathrm{Gd}$ & $\mathrm{Zr}$ \\
\hline Untreated & $\mathrm{A}$ & 96.87 & 2.86 & 0.06 & 0.32 \\
\cline { 2 - 6 } & $\mathrm{B}$ & 62.46 & 21.79 & 15.58 & 0.15 \\
\hline
\end{tabular}

The XRD pattern for the untreated ZE41 Mg alloy shows the presence of pure a-Mg phase and intermetallic phase $\mathrm{Mg}_{3} \mathrm{Zn}_{3} \mathrm{Gd}_{2}$ (Fig. 6). Hence, in light of the above EDX measurements the second eutectic phase observed in OM and SEM in the form of discontinuous islands along the grain boundary is $\mathrm{Mg}_{3} \mathrm{Zn}_{3} \mathrm{Gd}_{2}$. phase.

\subsection{Microstructure of ECAP ZE41 Mg alloy}

Fig. 7 shows the optical microstructure of ECAP Mg alloy processed at $250^{\circ} \mathrm{C}, 300^{\circ} \mathrm{C}$ and $350^{\circ} \mathrm{C}$ using route $\mathrm{B}_{\mathrm{C}}$ and $\mathrm{C}$ after 4 passes. Almost all the ECAP samples exhibited a bimodal grain size distribution consisting of fine grains surrounded with large grains except for the sample processed at $250{ }^{\circ} \mathrm{C}$ using route $\mathrm{C}$ (Table 2). Grain refinement occurs by dynamic recrystallization during ECAP and rate of grain refinement generally reduces as the ECAP temperature increases [33]. It is a well-known fact that grain refinement in ECAP increases when the recovery rates are reduced. But at higher temperatures recovery rates increase which leads to dislocation annihilation within the lattice instead of accumulating along the sub - grain walls. Further, development of microstructure with high angle grain boundaries would be difficult at higher temperature, thus sub-grain structure would be retained. Hence, homogenous grain refinement does not occur at high temperature [33].

Fig. 8 shows the microstructural changes occurring in ECAP ZE41 Mg alloys processed at $250^{\circ} \mathrm{C}$ using route $\mathrm{C}$. After 2 passes by ECAP, the initial large grains are deformed into smaller grains yielding a heterogeneous bimodal microstructure where the small grains are enclosed within the larger grains. In the bimodal microstructure, the large grains of $170 \mu \mathrm{m}$ surrounded the smaller $60 \mu \mathrm{m}$ grains with an overall 
average grain size of $89 \mu \mathrm{m}$ (Fig. 8a). After higher passes, homogenous and equiaxed grains were observed which attributed to grain refinement by dynamic recrystallization [34]. Average grain sizes of $40 \mu \mathrm{m}$ and $\sim 34 \mu \mathrm{m}$ were observed after 3 passes and 4 passes, respectively. The grain refinement after the third and fourth pass was nearly $78 \%$ and $74 \%$ compared to untreated sample due to the high rate of dislocation generation during the ECAP pass.

Table 2 Summary of grain size and mechanical properties for untreated and ECAP sample 


\begin{tabular}{|c|c|c|c|c|c|c|c|}
\hline State & Route & $\begin{array}{l}\text { ECAP } \\
\text { passes }\end{array}$ & $\begin{array}{l}\text { Ultimate tensile } \\
\text { strength } \\
\text { [MPa] }\end{array}$ & $\begin{array}{l}\text { Yield } \\
\text { strength } \\
\text { [MPa] }\end{array}$ & $\begin{array}{l}\text { Fracture } \\
\text { strain }\end{array}$ & $\begin{array}{l}\text { Grain } \\
\text { size } \\
{[\mu \mathrm{m}]}\end{array}$ & $\begin{array}{l}\text { Hardness } \\
{[\mathrm{Hv}]}\end{array}$ \\
\hline Untreated & - & 131.0 & 95.39 & 7.3 & $151 \pm 3$ & $67 \pm 5$ & \\
\hline \multirow[t]{8}{*}{$250^{\circ} \mathrm{C}$} & \multirow[t]{4}{*}{$\mathrm{B}_{\mathrm{C}}$} & 1 & 157.4 & 132.8 & 13.8 & $\begin{array}{l}122 \pm \\
19.2\end{array}$ & $71 \pm 8.1$ \\
\hline & & 2 & 158.4 & 139.4 & 14.0 & $\begin{array}{l}109 \pm \\
17.5\end{array}$ & $76 \pm 7.4$ \\
\hline & & 3 & 182.8 & 153.1 & 14.7 & $\begin{array}{l}102 \pm \\
11.8\end{array}$ & $78 \pm 4.1$ \\
\hline & & 4 & 187.4 & 168.8 & 15.3 & $\begin{array}{l}89 \pm \\
2.5\end{array}$ & $80 \pm 2.1$ \\
\hline & \multirow[t]{4}{*}{ C } & 1 & 171.3 & 141.0 & 10.1 & $\begin{array}{l}121 \pm \\
22.8\end{array}$ & $72 \pm 9.0$ \\
\hline & & 2 & 181.2 & 171.5 & 11.6 & $\begin{array}{l}49 \pm \\
12.9\end{array}$ & $76 \pm 6.3$ \\
\hline & & 3 & 199.2 & 172.4 & 14.6 & $\begin{array}{l}38 \pm \\
8.1\end{array}$ & $85 \pm 3.1$ \\
\hline & & 4 & 207.4 & 174.6 & 15.5 & $\begin{array}{l}33 \pm \\
2.5\end{array}$ & $90 \pm 1.2$ \\
\hline \multirow[t]{8}{*}{$300^{\circ} \mathrm{C}$} & \multirow[t]{4}{*}{$\mathrm{B}_{\mathrm{C}}$} & 1 & 170.6 & 129.6 & 13.1 & $\begin{array}{l}126 \pm \\
19\end{array}$ & $72 \pm 11.6$ \\
\hline & & 2 & 179.4 & 149.8 & 14.6 & $\begin{array}{l}95 \pm \\
13.4\end{array}$ & $76 \pm 8.6$ \\
\hline & & 3 & 187.5 & 151.5 & 15.3 & $\begin{array}{l}93 \pm \\
14.6\end{array}$ & $80 \pm 6.7$ \\
\hline & & 4 & 174.0 & 151.7 & 13.3 & $\begin{array}{l}89 \pm \\
10\end{array}$ & $81 \pm 1.4$ \\
\hline & \multirow[t]{4}{*}{ C } & 1 & 167.8 & 137.0 & 14.1 & $\begin{array}{l}130 \pm \\
20.2\end{array}$ & $70 \pm 8.9$ \\
\hline & & 2 & 176.3 & 168.3 & 12.6 & $\begin{array}{l}120 \pm \\
16.7\end{array}$ & $72 \pm 8.2$ \\
\hline & & 3 & 191.7 & 144.3 & 17.5 & $\begin{array}{l}112 \pm \\
16.7\end{array}$ & $75 \pm 5.5$ \\
\hline & & 4 & 195.8 & 147.8 & 13.8 & $\begin{array}{l}95 \pm \\
22\end{array}$ & $78 \pm 1.3$ \\
\hline $350^{\circ} \mathrm{C}$ & $\mathrm{B}_{\mathrm{C}}$ & 1 & 168.1 & 137.0 & 13.3 & $\begin{array}{l}135 \pm \\
19.2\end{array}$ & $69 \pm 8.9$ \\
\hline
\end{tabular}




\begin{tabular}{|c|c|c|c|c|c|c|}
\hline & 2 & 185.2 & 168.3 & 15.2 & $\begin{array}{l}134 \pm \\
15.4\end{array}$ & $71 \pm 6.8$ \\
\hline & 3 & 198.3 & 161.5 & 20 & $\begin{array}{l}106 \pm \\
13.1\end{array}$ & $73 \pm 4.5$ \\
\hline & 4 & 170.0 & 144.3 & 13.1 & $\begin{array}{l}94 \pm \\
16\end{array}$ & $75 \pm 1.2$ \\
\hline \multirow[t]{4}{*}{ C } & 1 & 184.8 & 172.3 & 14.1 & $\begin{array}{l}108 \pm \\
17\end{array}$ & $70 \pm 11.1$ \\
\hline & 2 & 187.2 & 162.4 & 14.0 & $\begin{array}{l}102 \pm \\
15.1\end{array}$ & $73 \pm 9.7$ \\
\hline & 3 & 196.2 & 155.0 & 16.5 & $\begin{array}{l}101 \pm \\
13.2\end{array}$ & $75 \pm 3.2$ \\
\hline & 4 & 180.0 & 147.9 & 12.5 & $\begin{array}{l}91 \pm \\
23\end{array}$ & $76 \pm 1.1$ \\
\hline
\end{tabular}

The EDX analysis shows that the grain interiors remain $\mathrm{Gd}$ deficient after ECAP at $250^{\circ} \mathrm{C}$ using route $\mathrm{C}$ irrespective of the number of passes (Table 3). While the $\mathrm{Mg}, \mathrm{Zn}$ and $\mathrm{Zr}$ contents remain within the standard deviation after three passes, a significant increase in the $\mathrm{Zr}$ content was observed after the fourth pass. On the other hand, only the $\mathrm{Mg}$ and $\mathrm{Zn}$ contents remain within the standard deviation after three passes within the second phase regions along the grain boundaries. Significantly large changes in the overall composition within the second phase regions were observed after the fourth pass.

Table 3 EDX analysis of ECAP samples using route $\mathrm{C}$ at $250^{\circ} \mathrm{C}$.

\begin{tabular}{|llllll|}
\hline ECAP & Regime & $\mathrm{Mg}$ & $\mathrm{Zn}$ & $\mathrm{Gd}$ & $\mathrm{Zr}$ \\
\hline $250^{\circ} \mathrm{C}-2$ passes & $\mathrm{A}$ & 96.82 & 2.86 & - & 0.32 \\
\cline { 2 - 6 } & $\mathrm{B}$ & 60.46 & 36.79 & 2.58 & 0.16 \\
$250^{\circ} \mathrm{C}-3$ passes & $\mathrm{C}$ & 96.65 & 2.93 & - & 0.42 \\
\cline { 2 - 6 } & $\mathrm{D}$ & 60.60 & 37.28 & 1.40 & 0.72 \\
$250^{\circ} \mathrm{C}-4$ passes & $\mathrm{E}$ & 96.53 & 2.33 & - & 1.14 \\
\cline { 2 - 6 } & $\mathrm{F}$ & 41.06 & 18.92 & 1.22 & 38.81 \\
\hline
\end{tabular}

In addition to the a-Mg phase in the untreated samples, XRD patterns also showed the presence of intermetallic $\mathrm{Mg}_{3} \mathrm{Gd}$ and $\mathrm{Zn}_{2} \mathrm{Zr}_{3}$ phases at higher ECAP passes [28] (Fig. 6). The intermetallic $\mathrm{Mg}_{3} \mathrm{Zn}_{3} \mathrm{Gd}_{2}$ phase was observed only after $4 \mathrm{ECAP}$ passes. The $\mathrm{Mg}_{3} \mathrm{Gd}$ phase normally shows a face-centered cubic structure like the $\mathrm{W}$-phase having a lattice parameter of $\mathrm{a}=0.74 \mathrm{~nm}[35,36]$. The fine-grained microstructure observed after 4 ECAP passes is attributed to the high thermal stability of this $\mathrm{Mg}_{3} \mathrm{Gd}$ 
phase [37], which prevents grain coarsening during heating and processing of the sample by ECAP (Fig. 8c) [38].

On the other hand, $\mathrm{Zn}_{2} \mathrm{Zr}_{3}$ has a tetragonal cubic structure with lattice parameters, $\mathrm{a}=0.763 \mathrm{~nm}$ and $\mathrm{c}=$

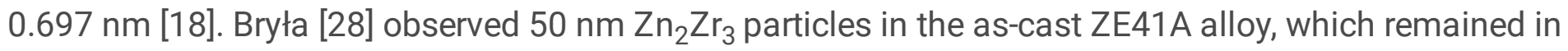
small quantities after ECAP [18]. Neil [39] observed $\mathrm{Zn}_{2} \mathrm{Zr}_{3}$ phase in EZ33A alloy both in as-cast and ECAP samples. While the increase in intensity of the peaks after 4 passes as compared to the untreated sample, is attributed to the overlapping peaks of different phases, the decrease in the intensity of the peaks after 2 passes maybe due to ECAP induced texture. For e.g., the intensity of the (0002) peak in the untreated $\mathrm{Mg}$ alloy is reduced after 2 ECAP passes, while after 4 ECAP passes the (0002) peak intensity increased.

These peak variations are produced by grain refinement during the ECAP process (peak broadens due to grain refinement). Koike et al. [40] observed that peak variations in ECAP samples are due to the activation of a slip process by the grain boundaries and texture modification is the effective strengthening mechanism in Mg alloys [25]. Further, they have noted that number of ECAP passes influences the variations in the peaks with stronger variations occurring at higher ECAP passes.

Fig. 9 shows the orientation maps (OMs) with IPF obtained from the center of the sample for both untreated and ECAP samples processed at $250^{\circ} \mathrm{C}$ using route $\mathrm{C}$ for 3 and 4 passes. The OMs in the Fig. 9 reveal the crystal orientations of each grain perpendicular to the PD (pressing direction) color coded with respect to the IPF. The untreated alloy showed an equiaxed microstructure with a normal grain size distribution (Fig. 10a). But large fractions of finer and deformed grains with no apparent texture were obtained after ECAP for three passes (Fig. 10b). The area fraction of $20 \mathrm{~mm}$ grains was $~ 140$ before ECAP, which reduced to $\sim 20$ and $\sim 15$ after 3 and 4 passes, respectively. Fig. 10c shows that majority of the grains range from $\sim 1$ to $5 \mathrm{~mm}$ after 4 passes. These large fractions of fine grains form as a result of DRX occurring during ECAP. The fraction of DRX grains increases with increase in the number of passes as observed in ECAP Mg-3.7Al-1.8Ca-0.4Mn alloy samples [41]. This non-uniform microstructure obtained after 3 and 4 passes is expected due to the larger than $90^{\circ}$ internal channel angles of the die used in this study [42].

Low angle grain boundaries are converted into high angle grain boundaries by dynamic recrystallization during ECAP $[43,44,45]$. In the present work, grain boundaries with misorientation angles more than $15^{\circ}$ were considered as high angle grain boundaries [46, 47, 48, 49]. Fig. 11 shows the change in the misorientation angle distribution for ECAP samples compared to the untreated sample. The misorientation angles of the grain boundary in the range of $3.4-8.4^{\circ}\left(<10^{\circ}-\right.$ LAGBs) has decreased from $90 \%$ in the untreated sample to $79 \%$ and $69 \%$ after 3 and 4 ECAP passes respectively [50].

Deformation during ECAP occurs by simple shear which induces large crystal rotations [ $51,52,53]$. The magnitude of the crystal rotations depends on the orientation of the slip system with respect to the shear stress. Large and small crystal rotations are achieved when the Burgers vector of the slip system is nearly 
perpendicular or aligned respectively to the shear direction. The crystals or grains tend to achieve their stable orientation with increasing strains from increase in the number of passes and retain the same irrespective of the shear strain sign. This favorable condition can be easily obtained for route $C$ in which the shear strain is changed for every consecutive pass preventing further rotations. But the grains will not be suitably oriented with respect to applied shear stress on using the route $\mathrm{B}_{\mathrm{C}}$ after every pass/rotation, resulting in the activation of non-basal slip systems [54]. Hence, effective grain reorientation occurs on using the route $\mathrm{C}$.

The Schmid factor distribution for the untreated and ECAP samples (Fig. 12) did not significantly change in the average values before and after the deformation. The Schmid factor fraction higher than 0.46 is for all the samples which indicates elastic strain energy produced during ECAP would be consumed by slip forming twins [55] . Jidong Zhang et al [56] in their work on steel have mentioned the reason for behavior could be due to the dislocation slip before to the formation of the deformed twin which operates as a cushion and hence Schmid factor number remain same during the starting of the deformation process.

The engineering stress-strain curves for untreated and ECAP samples processed at $250^{\circ} \mathrm{C}, 300^{\circ} \mathrm{C}$ and $350{ }^{\circ} \mathrm{C}$ using routes $\mathrm{B}_{\mathrm{C}}$ and $\mathrm{C}$ are shown in Fig 13 (a-f). In general, ECAP lead to a significant increase in the YS, UTS and fracture strain (FS) of all the samples processed at different temperature and routes after the first pass, as compared to untreated samples (Table 2). In the samples processed using route $B_{C}$, the YS increased, and grain size decreased linearly with increasing passes at $250^{\circ} \mathrm{C}$ (Fig. 14a\&C). The UTS did not change after the first and the second pass, increased significantly after the third and slightly after the fourth pass at $250^{\circ} \mathrm{C}$ (Fig. 15a). The FS increased linearly with a small slope with increasing passes after increasing significantly after the first pass at $250^{\circ} \mathrm{C}$ (Fig. 15C). The YS and grain size remained relatively constant after the first pass at $300^{\circ} \mathrm{C}$. On the other hand, the UTS and FS increased linearly with a small slope from the first to the third pass and decreased after the fourth pass at $300^{\circ} \mathrm{C}$. The YS dropped significantly after a large increase due to the first pass at $350^{\circ} \mathrm{C}$. The grain size also showed a large decrease after the first pass but decreased only after the third and fourth passes at 350 ${ }^{\circ} \mathrm{C}$. The UTS and FS showed a behavior similar to that observed at $300^{\circ} \mathrm{C}$ but with sharper increasing and decreasing slopes at $350^{\circ} \mathrm{C}$.

The YS increased significantly after the first and second passes but remained relatively constant after the third and fourth passes in the samples processed at $250^{\circ} \mathrm{C}$ using route $\mathrm{C}$ (Fig. $14 \mathrm{a} \& \mathrm{~b}$ ). The grain size decreased significantly corresponding to the YS with a small reduction after the third pass as well at 250 ${ }^{\circ} \mathrm{C}$. Both the UTS and FS increased linearly with a moderate slope at $250^{\circ} \mathrm{C}$. The YS increased sharply after the first and second passes, but decreased and remained relatively constant after the third and fourth passes at $300^{\circ} \mathrm{C}$. However, the UTS increased linearly with nearly the same slope at $250{ }^{\circ} \mathrm{C}$ with lower values at $300^{\circ} \mathrm{C}$. The FS varied irregularly by increasing and decreasing after every pass at $300^{\circ} \mathrm{C}$. On the other hand, the grain size decreased, and the $Y S$ increased linearly at $300^{\circ} \mathrm{C}$ and $350^{\circ} \mathrm{C}$ respectively. The grain size reduced significantly after the first pass, but decreased slightly at higher 
passes at $350^{\circ} \mathrm{C}$. Both the UTS and FS increase up to the third pass and decrease after the fourth with the rates in the FS being higher than the UTS.

The highest YS and UTS was obtained by processing at $250^{\circ} \mathrm{C}$ using route $\mathrm{C}$. The processing route $\mathrm{B}_{\mathrm{C}}$ provided the highest $\mathrm{FS}$ at $350^{\circ} \mathrm{C}$. After four passes, the routes $\mathrm{B}_{\mathrm{C}}$ and $\mathrm{C}$ provided the highest $\mathrm{YS}$ and UTS at $250^{\circ} \mathrm{C}$.

The rate of recovery increases with increase in the ECAP processing temperature and involves dislocation annihilation within the grains [33]. Also, retention of sub-grain structure occurs even though the fraction of high angle grain boundary is high during ECAP. This might contribute unfavorable situation during high temperature pressing condition. Many studies showed that better mechanical properties were obtained at relatively low rather than high ECAP temperature. For instance, Yuan et al. [57] obtained good strength and ductility by gradually reducing the ECAP temperature for ZK60 Mg alloy. The increase in the strength and ductility was attributed to precipitation hardening and grain refinement. ECAP at lower processing temperatures yields UFG microstructures [57- 60]. In addition, low ECAP temperature assists in obtaining a homogenous microstructure by suppressing dynamic recrystallization or dynamic grain growth due to the lower driving force [61]. However, texture induced softening exceeded grain size strengthening after ECAP using the route $B_{C}$ at $275^{\circ} \mathrm{C}$ in as-extruded AZ61 [62] and Mg-Zn-Ca for 4 passes at $250{ }^{\circ} \mathrm{C}$ alloys [60]. Processing at $250^{\circ} \mathrm{C}$ using route $\mathrm{C}$ after 3 and 4 passes revealed only grain refinement and no texture (Fig. 9). The strengthening mechanism is considered as a competition between texture induced softening and grain refinement in Mg alloys processed by severe plastic deformation processes [63]. The yield strength of materials increases with decrease in the grain size according to the following Hall-Petch relation $[64,65,66]$ :

\section{See formula 2 in the supplementary files.}

where, is the yield strength, is the lattice or friction stress, is the Hall-Petch constant and is the grain size. But, Lin et al. (2014) [67] showed that the Hall-Petch relation is applicable only when the grain size changes, while the texture remains constant. This is consistent with the initial decrease in yield strength despite grain refinement in the initial passes, and increase in yield strength after significant strains are induced and grain refinement occurs by more passes. In other words, texture induced softening becomes the dominant strengthening mechanism during initial ECAP passes. But at higher passes, significant increase in the YS occurs since strengthening due to grain refinement dominates the texture induced softening.

The yield strengths obtained by using routes $B_{C}$ and $C$ at $250{ }^{\circ} \mathrm{C}$ and route $B_{C}$ at $300{ }^{\circ} \mathrm{C}$ showed a positive Hall-Petch scaling (Fig. 16). In fact, a linear fit to the yield strengths obtained using route $\mathrm{C}$ at 250 ${ }^{\circ} \mathrm{C}$ yielded $\mathrm{a}=417 \mathrm{MPa} \cdot \mathrm{mm}^{1 / 2}$ and $=105 \mathrm{MPa}$, which was also exhibited by a AZ31 Mg alloy with a constant texture after ECAP $[68,69]$. On the other hand, a negative slope was exhibited by samples processed using both routes $\mathrm{B}_{\mathrm{C}}$ and $\mathrm{C}$ at $350^{\circ} \mathrm{C}$. 
The ZE41 Mg alloy showed a bimodal grain size distribution despite lowering the ECAP temperature after the first pass at $350{ }^{\circ} \mathrm{C}$ to the second at $300{ }^{\circ} \mathrm{C}$, third at $270{ }^{\circ} \mathrm{C}$ and fourth at $240{ }^{\circ} \mathrm{C}$ to prevent $\mathrm{DRX}$ and grain growth [28]. Nevertheless, the YS and UTS of the alloy after 4 ECAP passes were three factors higher than the as-cast alloy and were attributed to grain refinement. Chao et al. [70] observed a $142 \%$, $70.3 \%$ and $70.4 \%$ increase in the yield strength to $376 \mathrm{MPa}$, ultimate tensile strength to $477 \mathrm{MPa}$ and microhardness to $91.3 \mathrm{HV}$ respectively on cold drawn (8 passes at room temperature) as-extruded AZ31 Mg alloy wires. The high work hardening leading to these enhanced mechanical properties were attributed to the high dislocation density, profuse twinning and refinement in twin and grain sizes. Also, static recrystallization occurring during the heating of samples before conducting ECAP and dynamic recrystallization which occurs during ECAP promote the grain refinement [25]. The increase in yield strength to $231.5 \mathrm{MPa}$ and fracture elongation to $27.2 \%$ of a ZK60 Mg-Zn-Zr alloy after 4 ECAP passes at $493 \mathrm{~K}$ was also attributed to the concomitant grain refinement from $30 \mu \mathrm{m}$ to $\sim 0.8 \mu \mathrm{m}$ [71]. However, AZ31 Mg alloys processed by equal-channel angular extrusion showed that a fracture elongation of $47 \%$ could be attained due to activation of non-basal slip systems and dynamic recovery [40]. In addition,

extensive tensile twinning was observed during ductile failure in a rolled AZ31 Mg alloy with $47 \mathrm{MPa} \cdot \mathrm{m}^{1 / 2}$ notched fracture toughness [72].

The hardness of the samples increased linearly with increase in the number of ECAP passes in all cases except on using route $\mathrm{C}$ at $350^{\circ} \mathrm{C}$. The hardness ranged from $67 \mathrm{HV}$ in the untreated sample to a maximum of $80 \mathrm{HV}$ using route $\mathrm{B}_{\mathrm{C}}$ and $90 \mathrm{HV}$ using route $\mathrm{C}$ as seen in the Fig. 17. Friction stir processing of the ZE41 alloy showed a similar increase from $60 \mathrm{HV}$ to $85 \mathrm{HV}$ after one pass [73]. The hardness, $\mathrm{H}$ is related to the yield strength, of metals and alloys through the Tabor relation: See formula 3 in the supplementary files.

Hence, both the hardness and the yield strength should show similar trends with increasing pass number. But, the yield strength showed a linear trend similar to the hardness only at $250^{\circ} \mathrm{C}$ using route $\mathrm{B}_{\mathrm{C}}(\mathrm{Fig}$. 14a\&b).

The increase in the hardness is attributed to strain hardening, which dominates over the softening due to recovery/recrystallization. But, increasing the ECAP processing temperature from $250^{\circ} \mathrm{C}$ to $350^{\circ} \mathrm{C}$, decreases the hardness by about $15 \%$ after 4 ECAP passes. The high temperature leads to dislocation annihilation and provides large driving force for dislocation rearrangement [74]. Also, at higher temperatures grain coalescence and rotation occur easily, which could also reduce the hardness of the sample [75]. Among the different processing temperature and routes, ECAP processing at $250{ }^{\circ} \mathrm{C}$ using route $\mathrm{C}$ exhibited the largest $~ 34 \%$ increase in hardness from $67 \mathrm{HV}$ to $90 \mathrm{HV}$. The results of hardness are correlated to the yield strength and both the results are found to be interdependent.

\subsection{Fractography}

Mainly smooth cleavage facets are observed on the fracture surface of the untreated sample, which are characteristic of brittle fracture (Fig. 18a). But, certain regions of the fracture surface also contained in 
the form of small dimples and tearing ridges, albeit surrounded by large cleavage facets. Features such as dimples and tear ridges are indicative of a ductile mode of fracture despite grain refinement and increase in strength after ECAP, the mode of failure changed from brittle to ductile fracture. With an increasing number of ECAP passes, larger portions of the fracture surface were covered with uniform size $(130 \mathrm{~mm})$ fine-scaled dimples as shown in Fig. 18. The above fractography results shows that ECAP is an effective process to improve the ductility of ZE41 Mg alloys. Huang et al. [76] observed similar fracture mechanisms in a Mg-Al-Ca-Mn alloy exhibiting improved ductility after multi pass ECAP. Akin to the present study, a Mg-2Y-0.6Nd-0.6Zr alloy also exhibited a transition from brittle to ductile fracture with increased dimples and a tearing ridge on ECAP at higher temperatures [77].

\section{Conclusions}

Equal channel angular pressing was successfully carried out for the ZE41 Mg alloy at $250^{\circ} \mathrm{C}, 300^{\circ} \mathrm{C}$ and $350^{\circ} \mathrm{C}$ using routes $\mathrm{B}_{\mathrm{C}}$ and $\mathrm{C}$ up to 4 passes each. Correlating the microstructure and mechanical behavior obtained from tensile testing and fractography of samples from each case provided the following insights:

- ECAP processing at $250^{\circ} \mathrm{C}$ using route $\mathrm{C}$ was found to be the most effective temperature and route.

- The average grain size reduced by $77 \%$ to $~ 34 \mathrm{~mm}$ from $\sim 151 \mathrm{~mm}$ after four passes. The inhomogeneous coarse-grained initial microstructure was converted into a homogenous finer-grain size microstructure at higher passes. Homogenous microstructures were obtained as a result of dynamic recrystallization taking place during ECAP processing. Above $250^{\circ} \mathrm{C}$, grain growth followed dynamic recrystallization resulting in an increase in the grain size, which lead to a decrease in the yield strength.

- The yield strength, UTS, and fracture strain increased after 4 ECAP passes as compared to the untreated ZE41 Mg alloy. Nearly $83 \%$ increase in YS, 58\% increase in UTS, and 107\% increase in fracture strain were observed after 4 ECAP passes for $250^{\circ} \mathrm{C}$ route $\mathrm{C}$ sample. These large enhancements in the tensile properties are attributed to grain refinement.

- Fractography showed that a transition from brittle to ductile fracture occurs at higher ECAP passes, as evidenced by the fine and uniform dimples compared to the cleavage facets on the fracture surface before ECAP.

\section{Declarations}

\section{Acknowledgements:}

Authors would like to thank the management and Prof Sudheer M (Head of the Department), Mechanical Engineering of St. Joseph engineering college, Mangaluru and Prof Anandhan Srinivasan (Head of the Department), Metallurgy and materials engineering, NITK and Dr Sumanth (Assistant professor at NITK) 
and Mangalore University for providing lab facilities to carry out this research work. Authors would like to thank Prof Rejin Raghavan, IISc, Bengaluru for his assistance and support given in this paper.

\section{References}

[1] F.S. Pan, M.B. Yang, X.H. Chen, J Mater Sci Technol 32, 1211(2016).

[2] W. Liu, J.S. Zhang, L.Y. Wei, C.X. Xu, X.M. Zong, J.Q. Hao, Mater. Sci. Eng. A 681, 97 (2017).

[3] S. Cohen, Goren-Muginstein, S. Avraham, B. Rashkova, G. Dehm, M. Bamberger, Z. Met 96, 1081(2005).

[4] Y. Wang, W. Rong, Y.J. Wu, L.M. Peng, J. Chen, W.J. Ding, J. Alloys Compd 698, 1066(2017).

[5] Wang JF, Song PF, Huang S, Pan FS. Mater. Lett 2016; 93: 415-418.

[6] J.S. Zhang, W.B. Zhang, L.P. Bian, W.L. Cheng, X.F. Niu, C.X. Xu, S.J. Wu, Mater. Sci. Eng. A 585, 268(2013).

[7] L. Gao, R.S. Chena, E.H. Han, J. Alloys Compd 481, 379(2009).

[8] M. Bamberger, G. Dehm, Annu. Rev. Mater. Res 38, 505(2008).

[9] L. Wen-cai, J. Long-kang, C. Liang, M. Jun, W. Guo-hua, Z. Song, X. Lu, W. Shao-hua, D. Wen-jiang, Mater. Des 59, 466(2014).

[10] Q.Z. Liu, X.F. Ding, Y.P. Liu, X.J. Wei, J. Alloys Compd 690, 961(2016).

[11] X.H. Shao, Z.Q. Yang, X.L. Ma, Acta Mater 58, 4760(2010).

[12] J.C. Li, Z.L. He, P.H. Fu, Y.J. Wu, L.M. Peng, W.J. Ding, Mater. Sci. Eng. A 651, 745(2016).

[13] J.C. Yu, Z. Liu, Y. Dong, Z. Wang, J. Magn. Alloy 3, 134(2015).

[14] X. Wu, F.S. Pan, R.J. Cheng, S.Q. Luo, Mater. Sci. Eng. A 726, 64(2018).

[15] W.J. Ding, Y.J. Wu, L.M. Peng, X.Q. Zeng, G.Y. Yuan, D.L. Lin, J Mater Res 24, 1842(2009).

[16] M.O. Pekguleryuz, A.A. Kaya, Adv. Eng. Mater 5, 866(2003).

[17] M.M. Avedesian, H. Baker, ASM specialty handbook: Magnesium and magnesium alloys. (ASM International. Materials Park, 1999) p 15.

[18] R. Ding, C. Chung, Y. Chiu, P. Lyon, Mater. Sci. Eng. A 527, 3777(2010).

[19] Z. Ruslan, Valiev Terence, G. Langdon, Prog. Mater. Sci 51, 881(2006). 
[20] R.Z. Valiev, A.V. Korznikov, R.R. Mulyukov, Mater. Sci. Eng. A 168, 141(1993).

[21] Z. Fan, Z. Ke-xiang, T. Cheng-wen, Y. Xiao-dong, M. Hong-lei, W. Fu-chi, C. Hong-nian, T Nonferr Metal Soc China 21, 2140(2011).

[22] M.S. Arun, Uday Chakkingal, J. Mater. Eng. Perform 27, 1352(2018).

[23] Majid Al-Maharbi, Ibrahim Karamana, J. Irene, Beyerlein, David Foley, K. Ted Hartwig, J. Laszlo, Kecskes, N. Suveen, Mathaudhu, Mater. Sci. Eng. A 528, 7616(2001).

[24] H. Yan, R.S. Chen, E. Han, Mater. Charact 62, 321(2011).

[25] K.R. Gopi, H. Shivananda Nayaka, Sandeep Sahu, Arab J Sci Eng 42, 4635(2017).

[26] Y. Liu, Z.X. Kang, L.L. Zhou, J.Y. Zhang, Y.Y. Li , Corros Eng Sci Techn 51, 256(2016).

[27] K. Yan, J. Bai, H. Liu, Z. Yang Jin, J Magnes Alloy 5, 336(2017).

[28] K. Bryła, Mater. Sci. Eng. A 772, 138750(2020).

[29] K. Nakashima, Z. Horita, M. Nemoto, T.G. Langdon, Mater. Sci. Eng. A 281, 82(2000).

[30] Xin Qiu, Qiang Yang, Kai Guan, Fanqiang Bu, Zhan-Yi Cao, Yong-Bing Liu, JianMengRare Metals 36, 962(2017).

[31] B.P. Chiranth, C. Siddaraju, T. Ram Prabhu, J. Mater. Eng. Perform 28, 3393(2019).

[32] Y. Liu, G.Y. Yuan, C. Lu, W.J Ding, Scr. Mater 55, 919(2006).

[33] M.Avvari, S. Narendranath, M. Able, Adv Mech Eng 8,1(2016).

[34] K.R. Gopi, H. Shivananda Nayaka, Sandeep Sahu,J. Mater. Eng. Perform 25,3737(2016).

[35] J.F. Nie, Metall Mater Trans A 43, 3891(2012).

[36] L. Luo, Y. Liu, M. Duan, Materials (Basel) 11, 1351(2018).

[37] P. Qiuming, M.A. Ning, L.I. Hui, J Rare Earths, 30, 1064(2012).

[38] 0. Tomomichi, K. Yasunori, Y. Kentaro, H. Hiroaki, K. Sigeharu, K. Yo, Mater. Trans 49, 2185(2008).

[39] W.C. Neil, M. Forsyth, P.C. Howlett, C.R. Hutchinson, B.R.W. Hinton, Corros. Sci 53, 3299(2011).

[40] J. Koike, T. Kobayashi, T. Mukai, H. Watanabe, M. Suzuki, K. Maruyama, K. Higashi, Acta Mater 51, 2055(2003).

[41] C.E. Wang, M.A. Aibin, Metals 9, 767(2019). 
[42] Kiyotaka Nakashima, Zenji Horita, Minoru Nemoto, Terence G Langdon, Acta Mater 46, 1589(1998).

[43] Taku Sakai, Andrey Belyakov, Rustam Kaibyshev, Hiromi Miura, John J Jonas, Prog. Mater. Sci 60, 130(2014).

[44] P.W.J. Mckenzie, R. Lapovok, Acta Mater 58, 3198(2010).

[45] V.V. Stolyarov, Y.T. Zhu, I.V. Alexandrov, T.C. Lowe, R.Z. Valiev, Mater. Sci. Eng. A 299, 59(2001).

[46] Myrjam Winning, Anthony D Rollett, Acta Mater 53, 2901(2005).

[47] B. Tolaminejad, K. Dehghani, Mater. Des 34, 285(2012).

[48] M. Reihanian, R. Ebrahimi, M.M. Moshksar, D. Terada, N. Tsuji, Mater. Charact 59, 1312(2008).

[49] D.J. Lloyd, D. Kenny, Acta Metall 28, 639(1980).

[50] Somjeet Biswas, Satyaveer Singh Dhinwal, Satyam Suwas, Acta Mater 58, 3247(2010).

[51] K. Mathis, E.F. Rauch, Mater. Sci. Eng. A 462, 248(2007).

[52] V.M. Segal, Mater. Sci. Eng. A 271, 322(1999).

[53] V.M. Segal, Mater. Sci. Eng. A 197, 157(1995).

[54] T. Kraj nak, P. Minarik, J. Gubicza, K. Mathis, R. Kuzel, M. Jane cek, Mater. Charact 123, 282(2017).

[55] H. Chen, F. Li, J. Li, X. Ma, J. Li, Q. Wan, Mater. Sci. Eng. A 671, 17(2016).

[56] Jidong Zhang, Weixue Han, Wenliang Rui, Jinghui Li, Zhenyi Huang, Fengli Sui. J. Mater. Eng 29, 1253(2020).

[57] Y.C. Yuan, A.B. Ma, X.F. Gou, J.H. Jiang, G. Arhin, D. Song, H. Liu, Mater. Sci. Eng. A 677, 125(2016).

[58] M. Gzyl, A. Rosochowski, S. Boczkal, L. Olejnik, Mater. Sci. Eng. A 638, 20(2015).

[59] G. Purceka, O. Saray, M.I. Nagimov, A.A. Nazarov, I.M. Safarov, V.N. Danilenko, O.R. Valiakhmetov, R.R. Mulyukov, Philos Mag 92, 690(2012).

[60] L.B. Tong, M. Zheng, H. Chang, X.S. Hu, K. Wu, S.W. Xu, S. Kamado, Y. Kojima, Mater. Sci. Eng. A 523, 289(2009).

[61] S.H. Kang, Y.S. Lee, J.H. Lee, J. Mater. Process. Technol 201, 436(2008).

[62] W. Kim, S. Hong, Y. Kim, S. Min, H. Jeong, J. Lee, Acta Mater 51, 3293 (2003).

[63] D. Panda, S. Sabat Suwas, V.D. Hiwarkar, S.K. Sahoo, Philos Mag 99, 1362(2019). 
[64] E.O. Hall, Proc. Phys. Soc., B 64, 747(1951).

[65] N.J. Petch, J. Iron, Steel Inst 174, 25(1953).

[66] T. Nieh, Wadsworth, J. Scripta Metall. Mater 25, 955(1991).

[67] J. Lin, W. Ren, Q. Wang, L. Ma, Y. Chen, Adv Mater Sci Eng 1 (2014).

[68] W.J. Kim, H.T. Jeong, Mater. Trans 46, 251(2005).

[69] H. Yu, Y. Xin, M. Wang, Q. Liu, J Mater Sci Technol 34, 248(2018).

[70] H.Y. Chao, H.F. Sun, W.Z. Chen, Mater. Charact 62, 312(2011).

[71] D.L. Yin, H.L. Cui, Joyce Qiao, J.F. Zhang, Mater. Res. Innov 19, S9-28 (2015).

[72] N. Subrahmanya Prasad, N. Naveen Kumar, R. Narasimhan, S. Suwas, Acta Mater 94, 281(2015).

[73] V.V. Kondaiaha, P. Pavanteja, M. Mani Manvit, R. Ramesh Kumara, R. Ganesh Kumar, B. Ratna Sunil, Proc Mater. Today 18, 125(2019).

[74] A. Belyakov, T. Sakai, H. Miura, K. Tsuzaki, Philos Mag A 81, 2629 (2001).

[75] J.P. Li, J. Shen, X.D. Yan, B.P. Mao, Trans. Nonferrous Met. Soc. China 20, 189 (2010).

[76] H. Huang, L. Huan, W. Ce, S. Jiapeng, B. Jing, X. Feng, J. Jinghua, A.J. Ma, Magnes. Alloy 7, 617 (2019).

[77] Y. Tan, W. Li, W. Hu, X. Shi, L. Tian, Materials (Basel)12, 1554(2019).

\section{Figures}




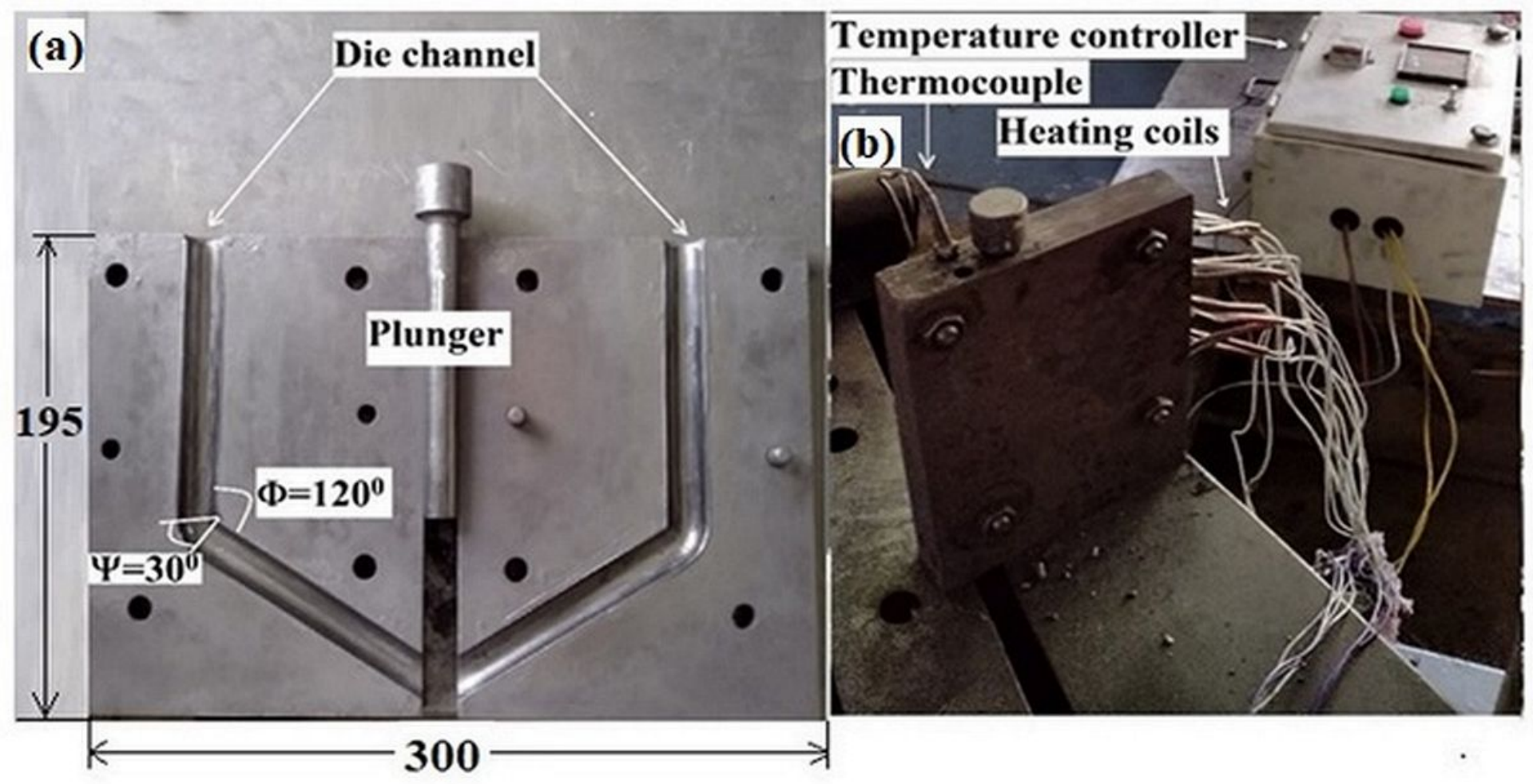

Figure 1

Equal channel angular pressing die setup: a) Die halves showing the intersecting internal channels and plunger and b) Assembled die and heating system (heating coils, thermocouple, and temperature controller). 

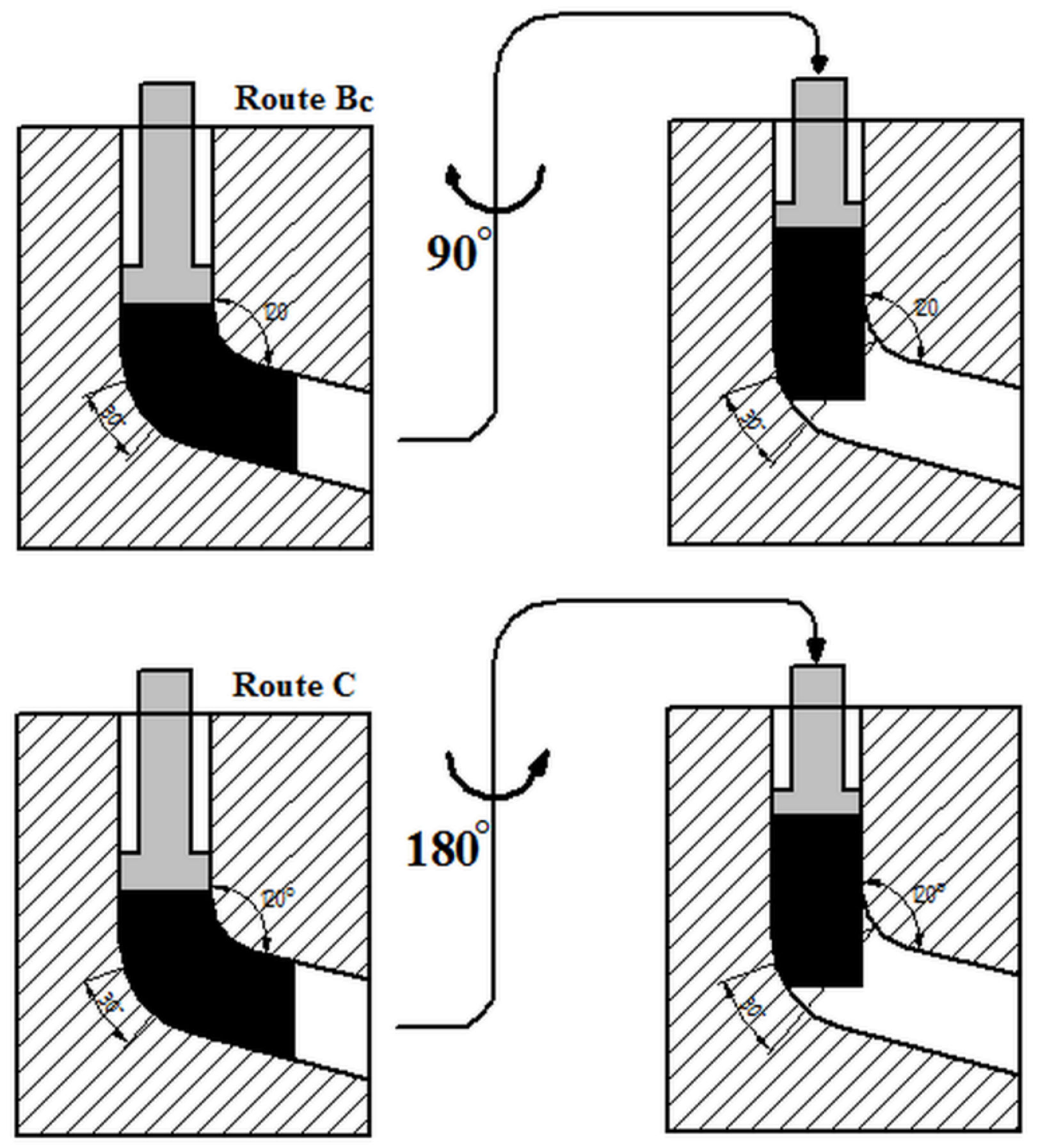

Figure 2

Schematic diagram of ECAP routes used in this study. 


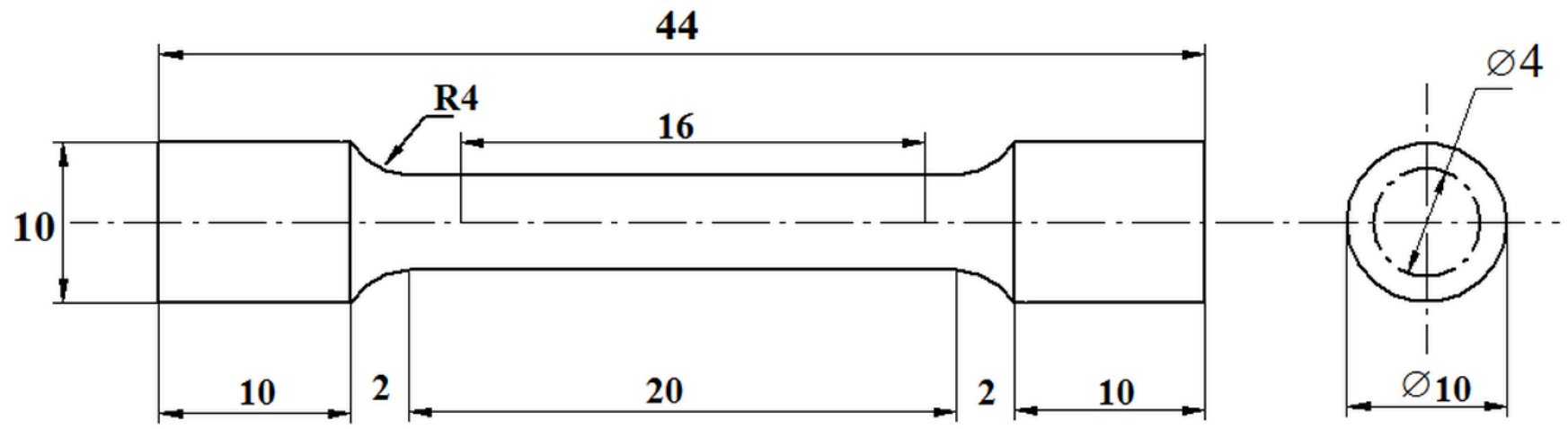

Figure 3

Schematic diagram of tensile sample.
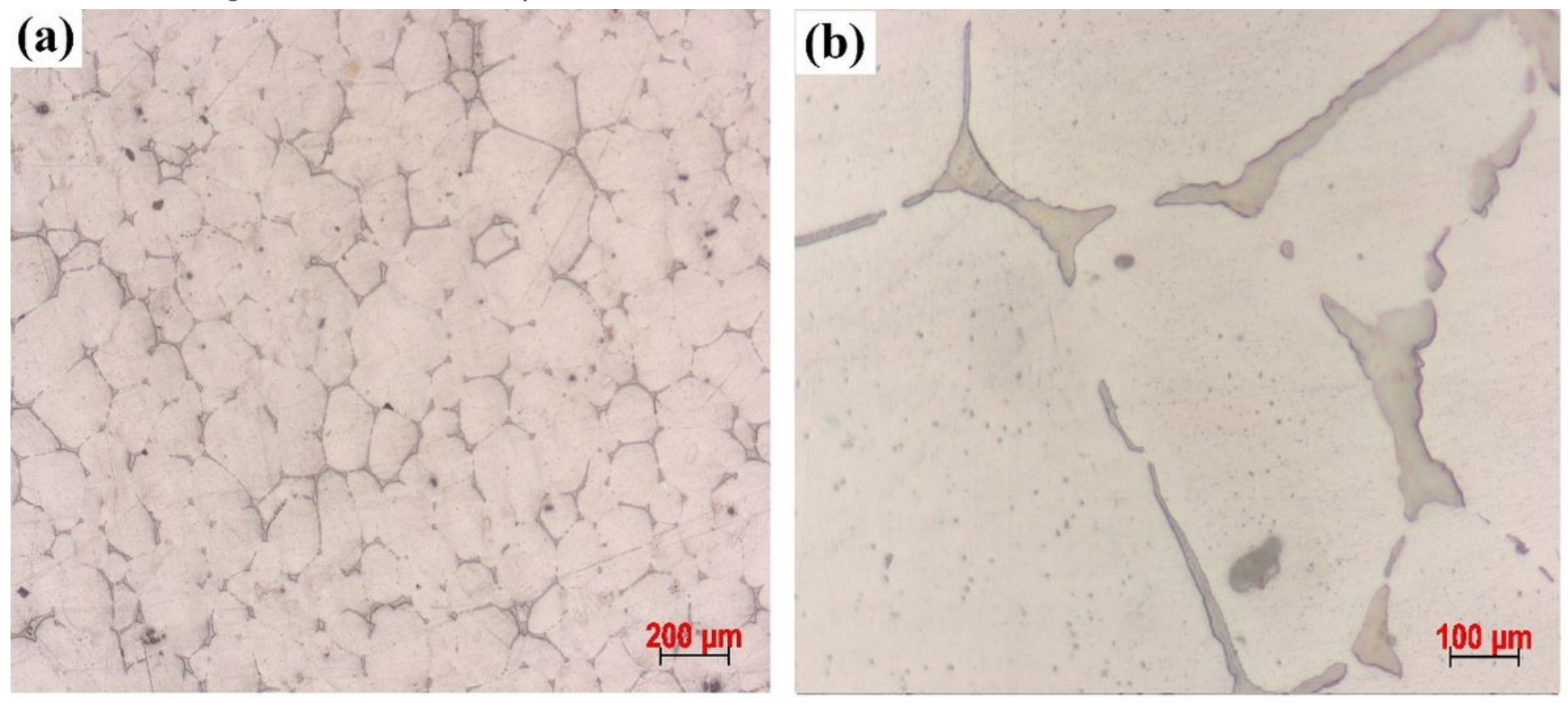

Figure 4

Optical micrographs of untreated ZE41 Mg alloy revealing: (a) close to an equiaxed microstructure (b) distinctly discontinuous second "eutectic" phase along the grain boundaries. 


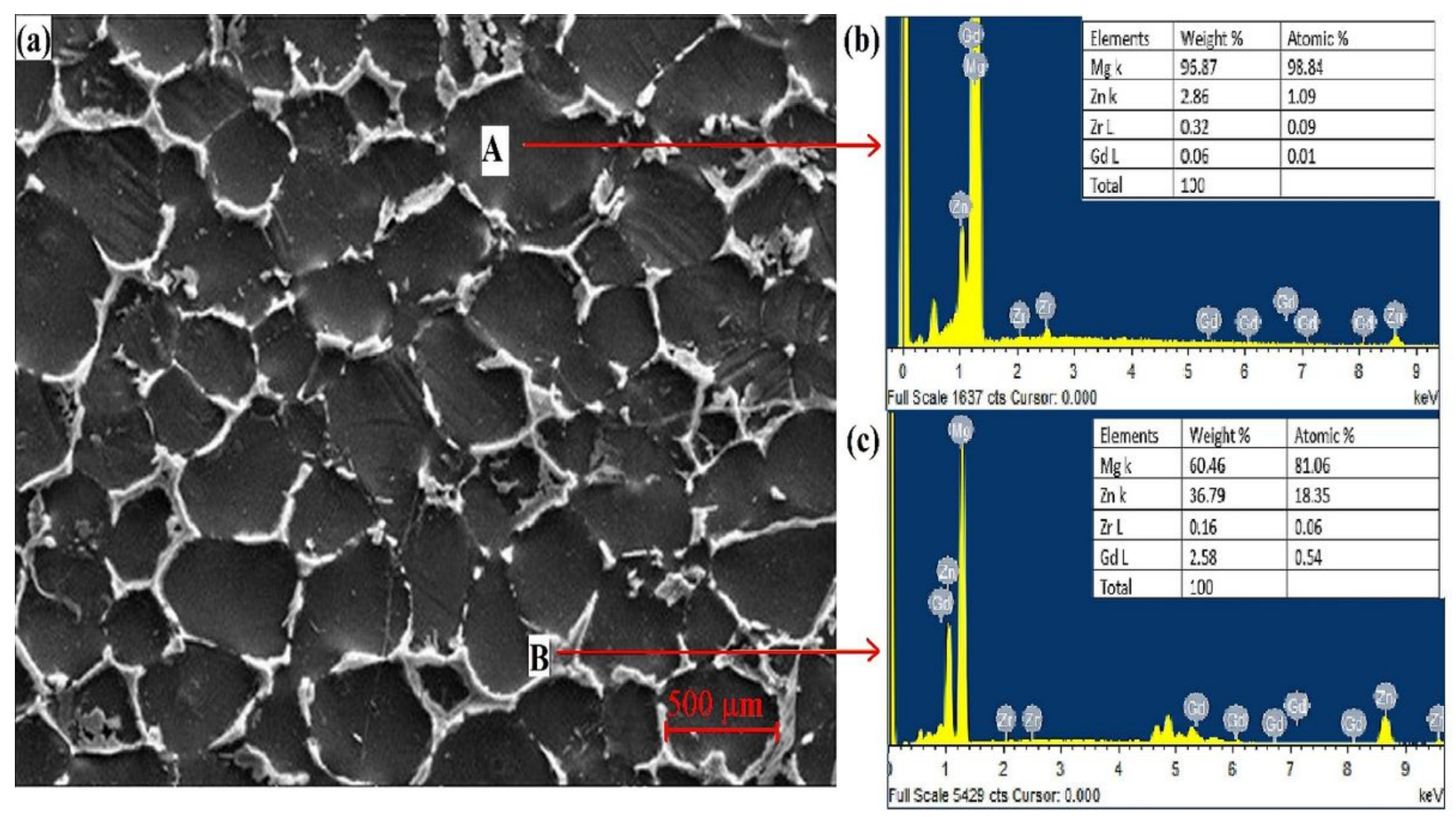

Figure 5

SEM image and EDX spectra from the bulk and second phase along grain boundary of etched untreated ZE41 Mg alloy [31]. 


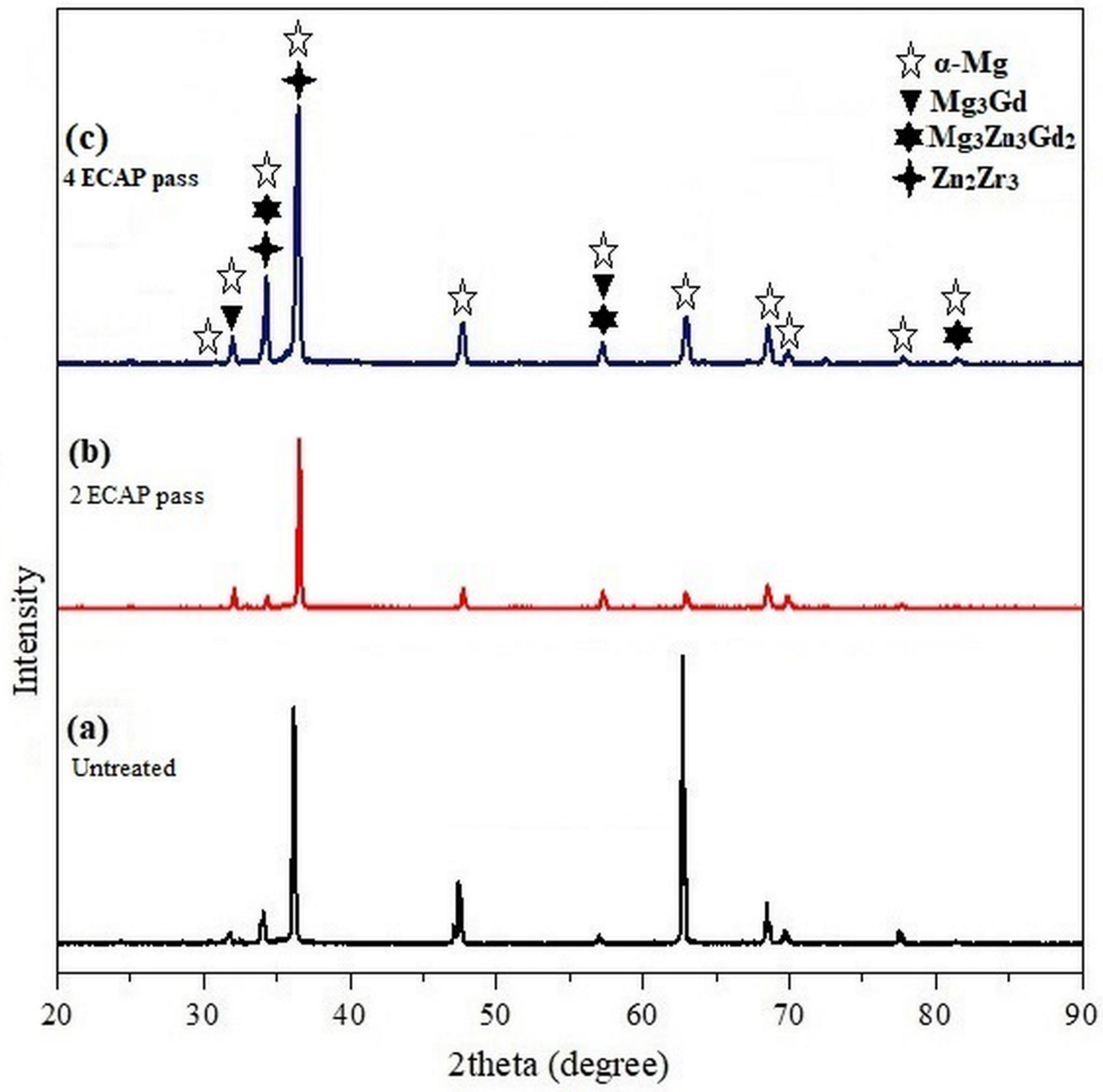

Figure 6

XRD patterns for (a) untreated samples and samples processed using route $C$ at $250 \mathrm{oC}$ for (b) 2, and (c) 4 ECAP passes. 

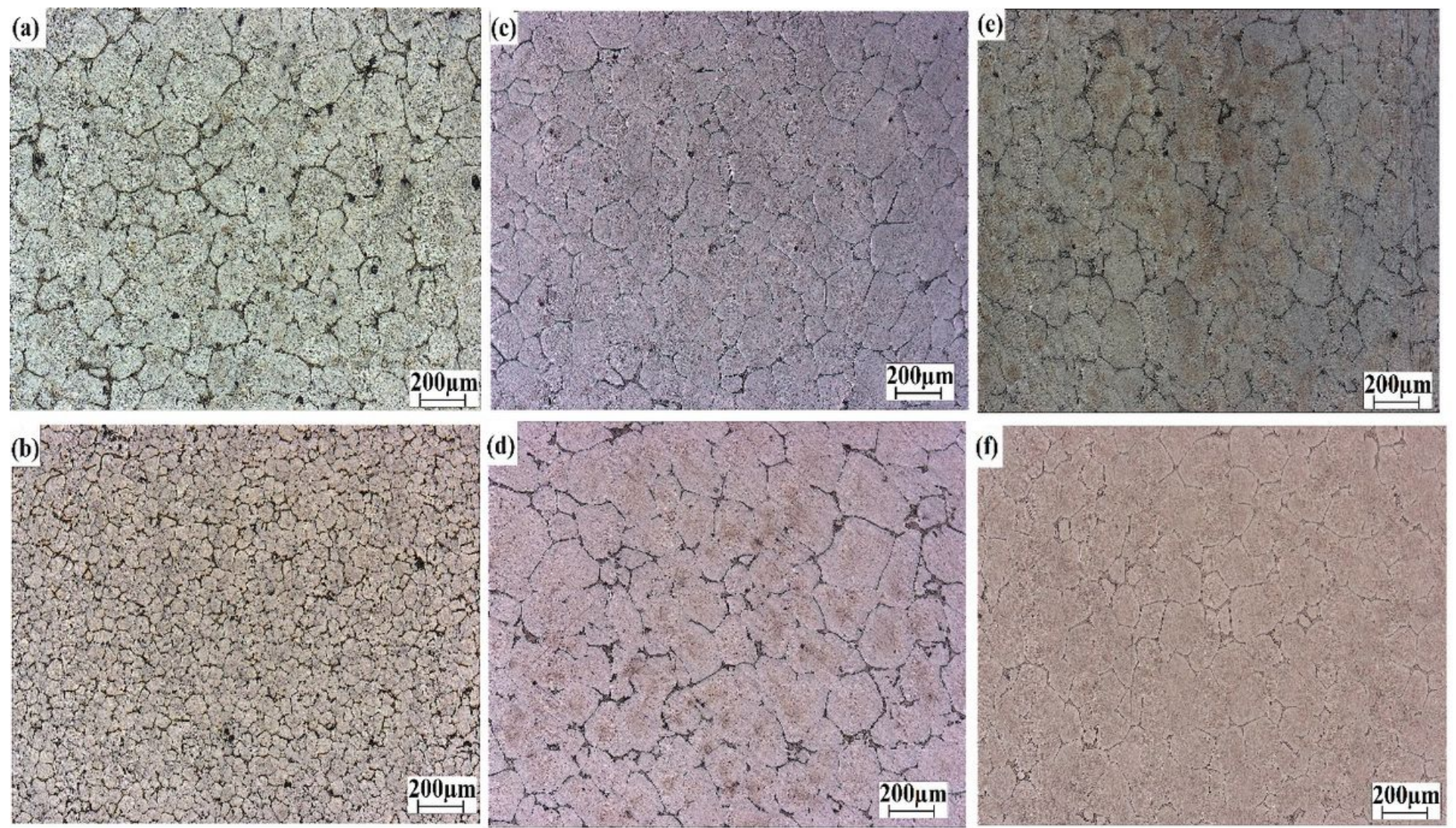

\section{Figure 7}

Optical micrographs of ECAP ZE41 Mg alloy samples processed at $250 \mathrm{OC}, 300 \mathrm{oC}$ and $350 \mathrm{oC}$ using routes $(a, c, e) B C$ and (b,d.f) $C$ after 4 passes. 

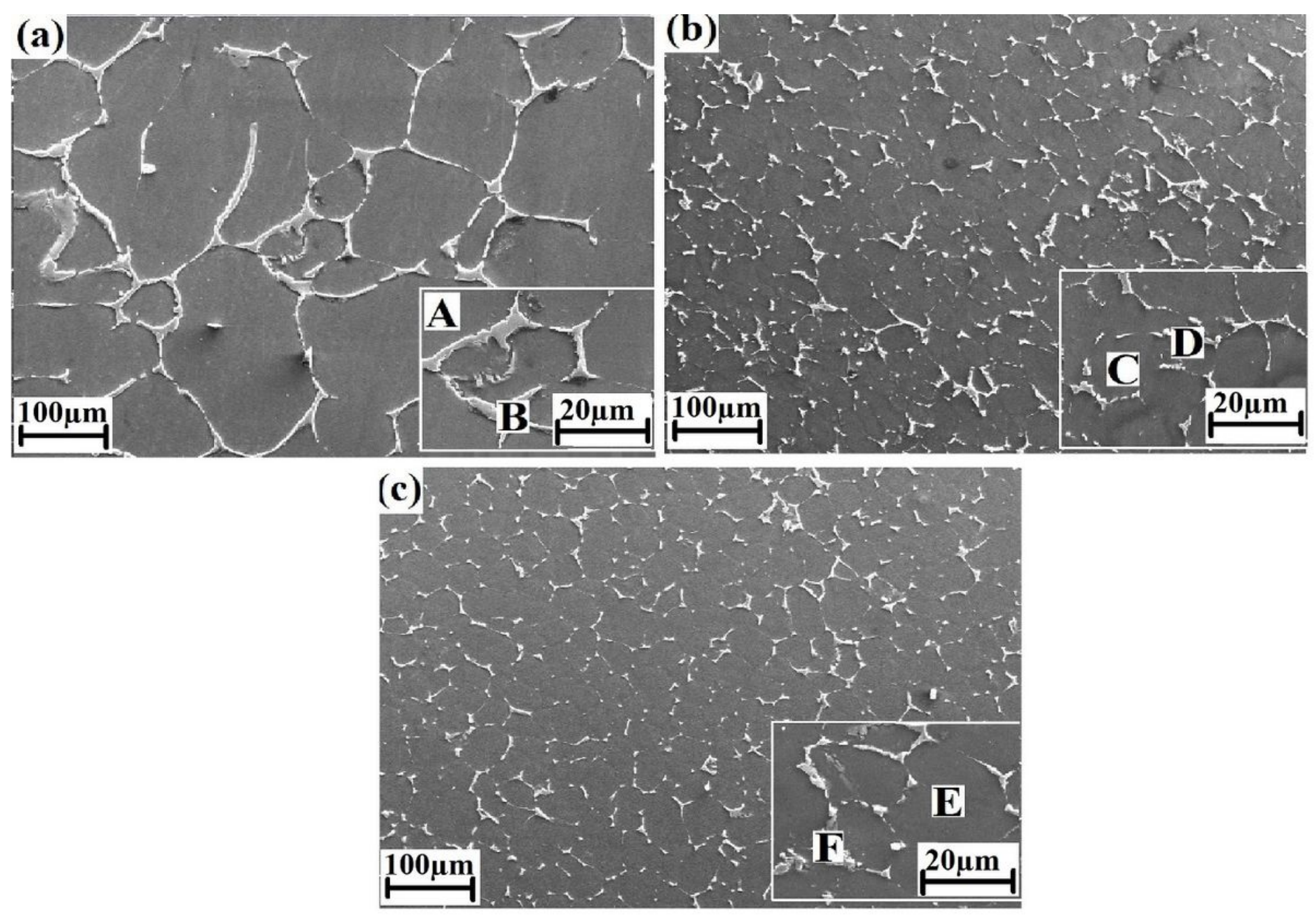

Figure 8

SEM image of ECAP ZE41 Mg alloy processed at 250 oC using route $C$ after: (a) 2 passes (b) 3 passes and (c) 4 passes.
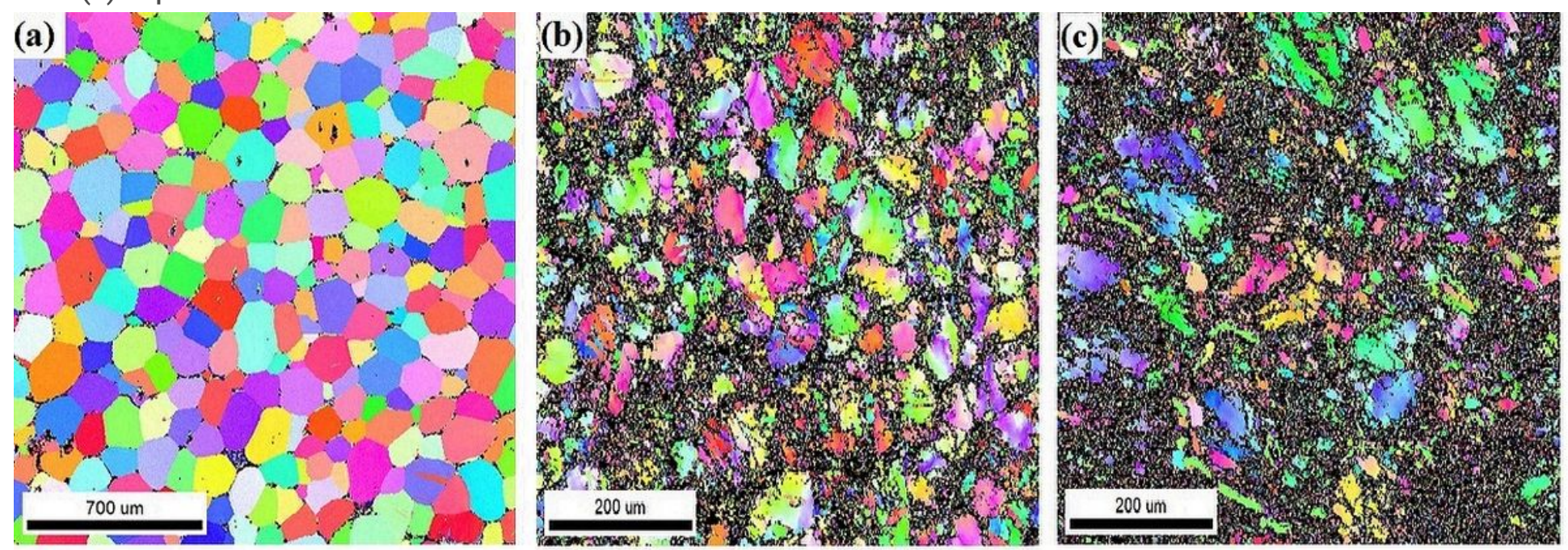

(d)

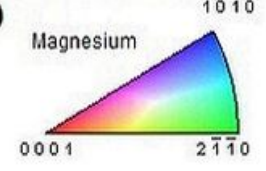


Figure 9

Orientation maps of ZE41 Mg alloy samples (a) untreated and processed at $250 \mathrm{oC}$ using route $\mathrm{C}$ after (b) 3 passes, (c) 4 passes and corresponding (d) inverse pole figure. The dark spots/regions could not be indexed.
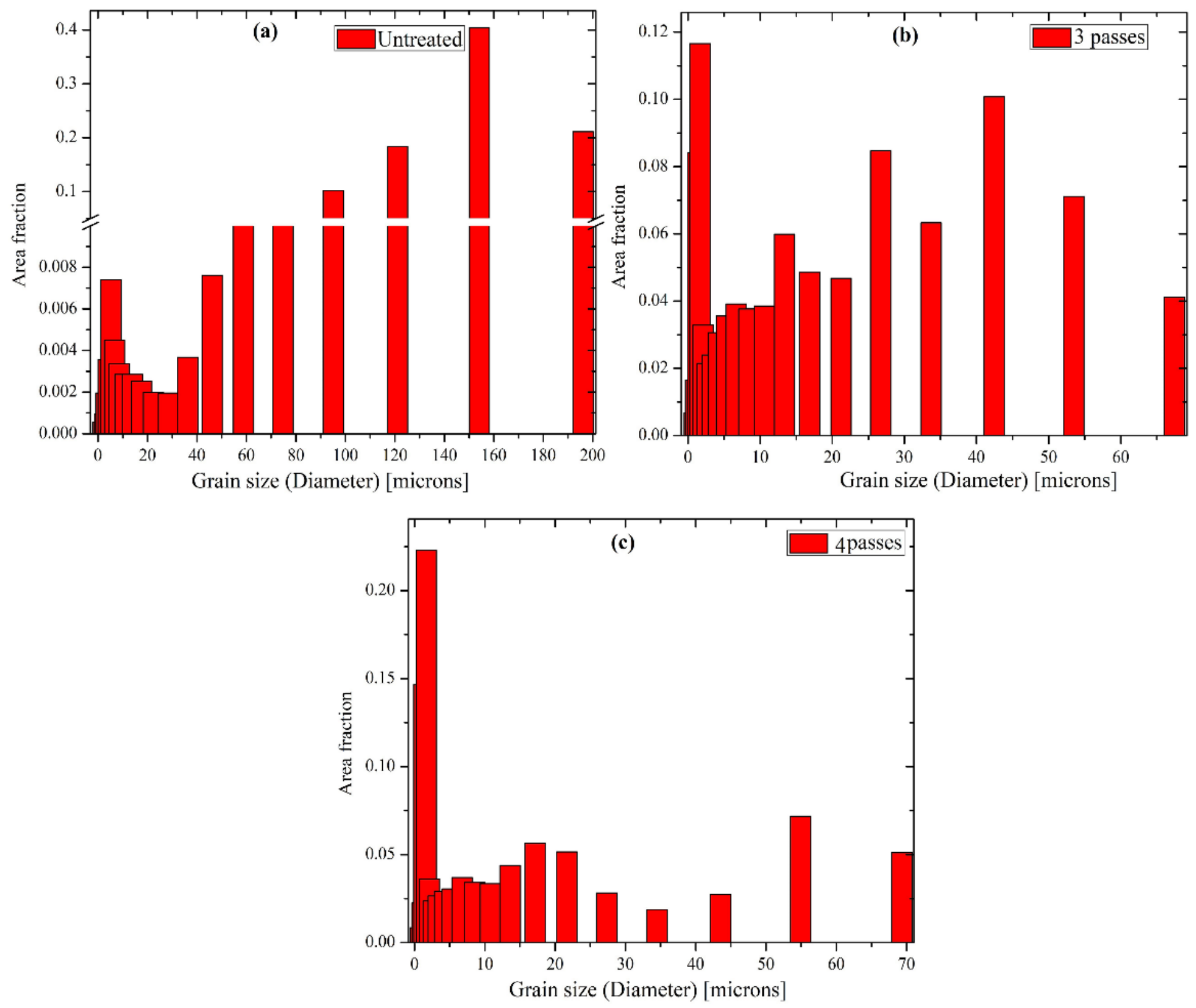

Figure 10

Grain size distribution of the ZE41 Mg alloy samples (a) untreated, ECAP processed at 250 oC using route $C$ for (b) 3 and (c) 4 passes. 

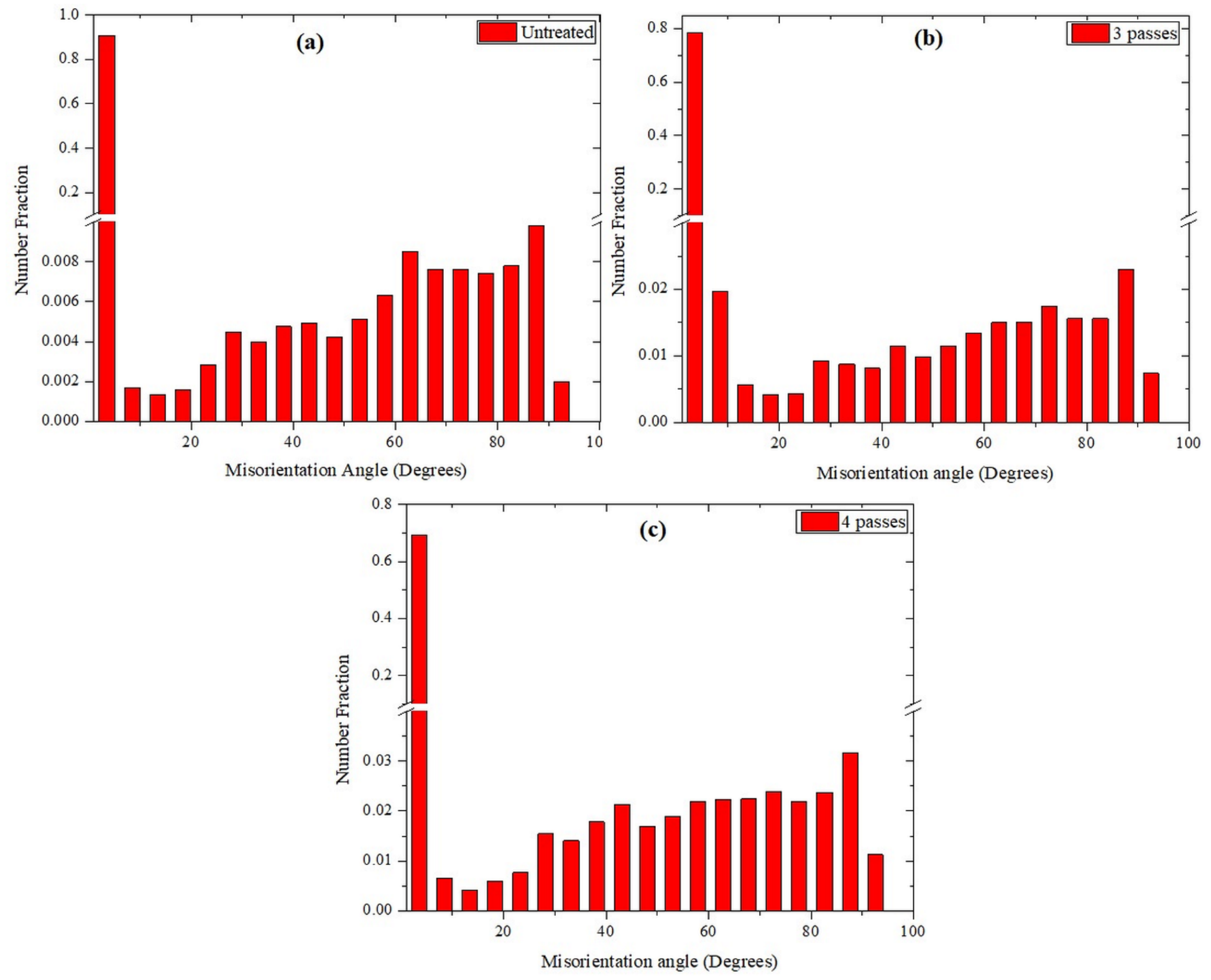

Figure 11

Misorientation angle distributions of (a) untreated and ECAP ZE41 Mg alloy processed at $250 \mathrm{oC}$ using route $C$ (b) 3 passes (c) 4 passes. 

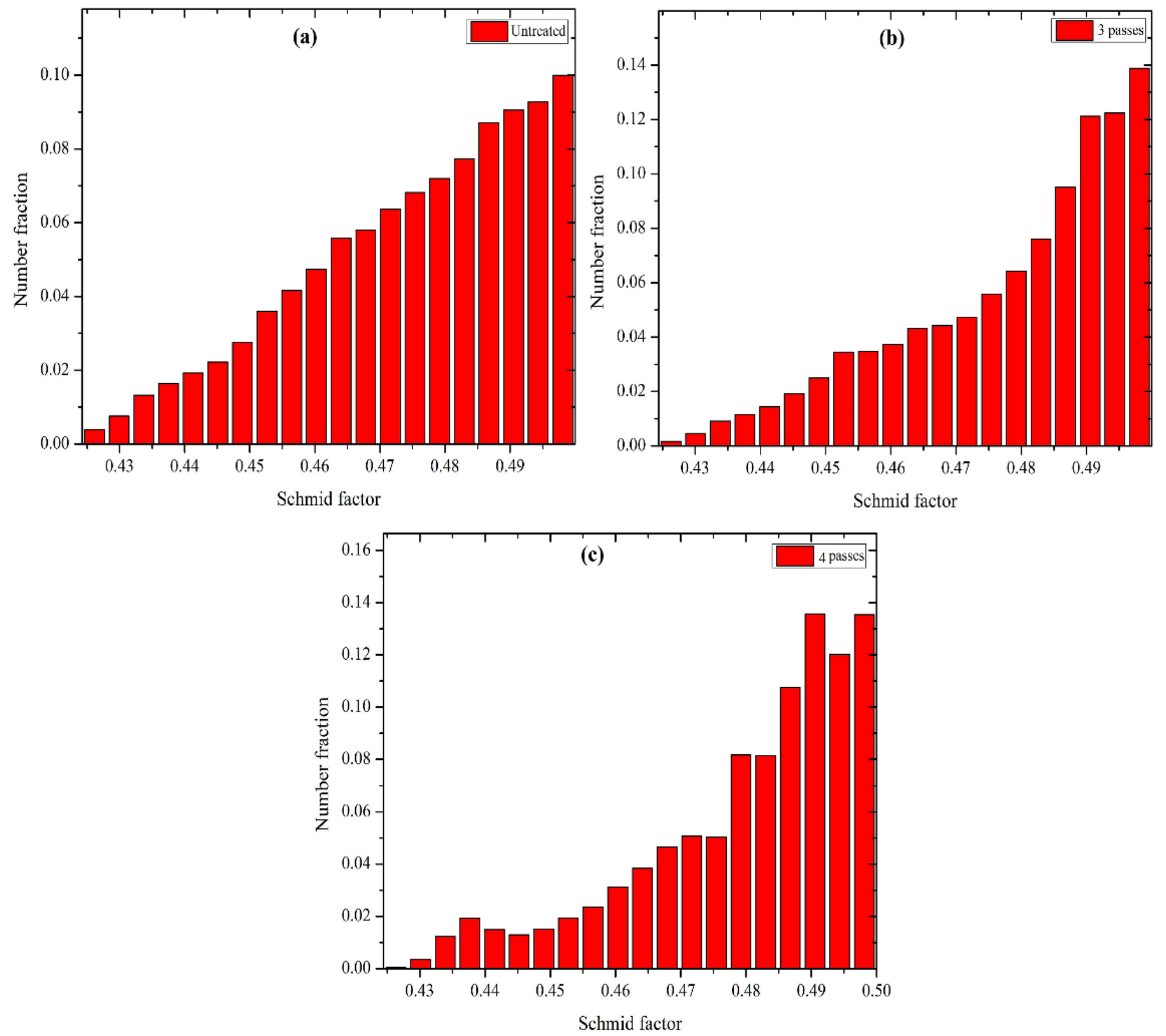

Figure 12

Schmid factor distribution of the (a) untreated and ECAP ZE41 Mg alloy processed at 250 oC using route C for (b) 3 passes (c) 4 passes. 

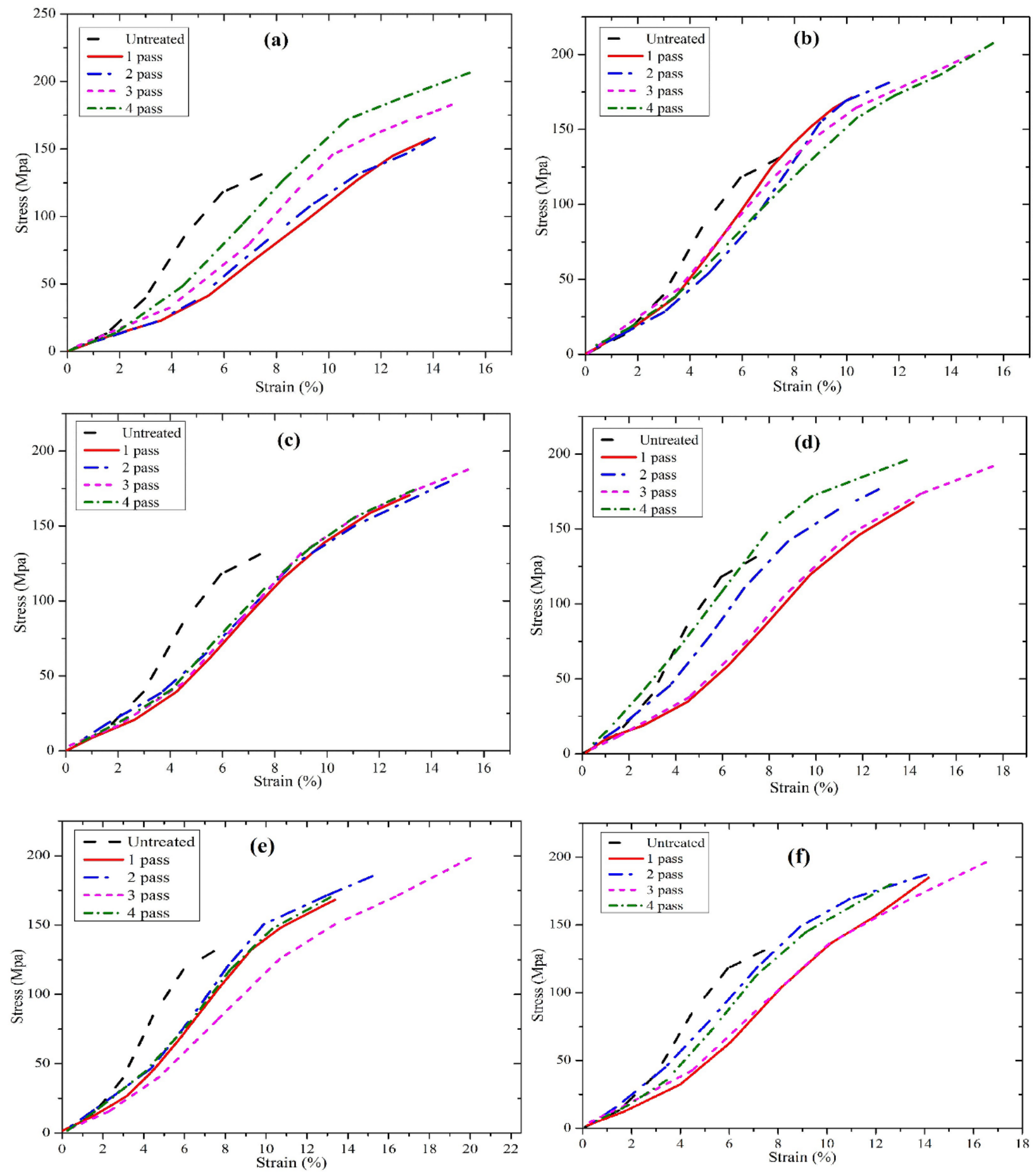

\section{Figure 13}

Engineering stress-strain curves for the untreated and ECAP samples processed at 250 oC using (a) route $B c$ and (b) route $C, 300 \circ C$ using (c) route $B C$ and (d) route $C$, and 350 oC using (e) route $B C$ and (f) route C. 

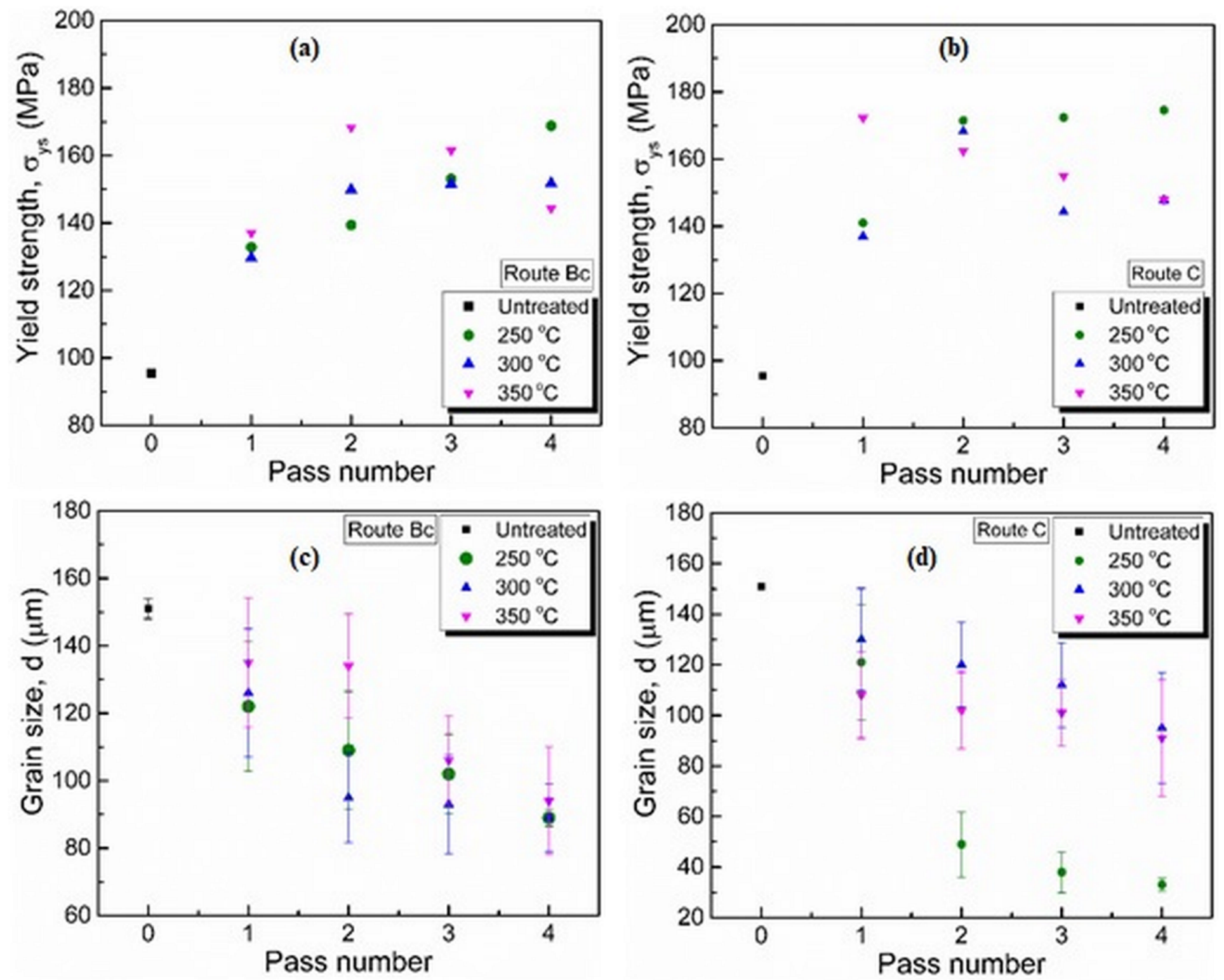

Figure 14

Variation of $(a \& b)$ yield strengths and (c \& d) grain sizes of untreated and ECAP samples processed at different temperatures and routes as a function of number of passes. 

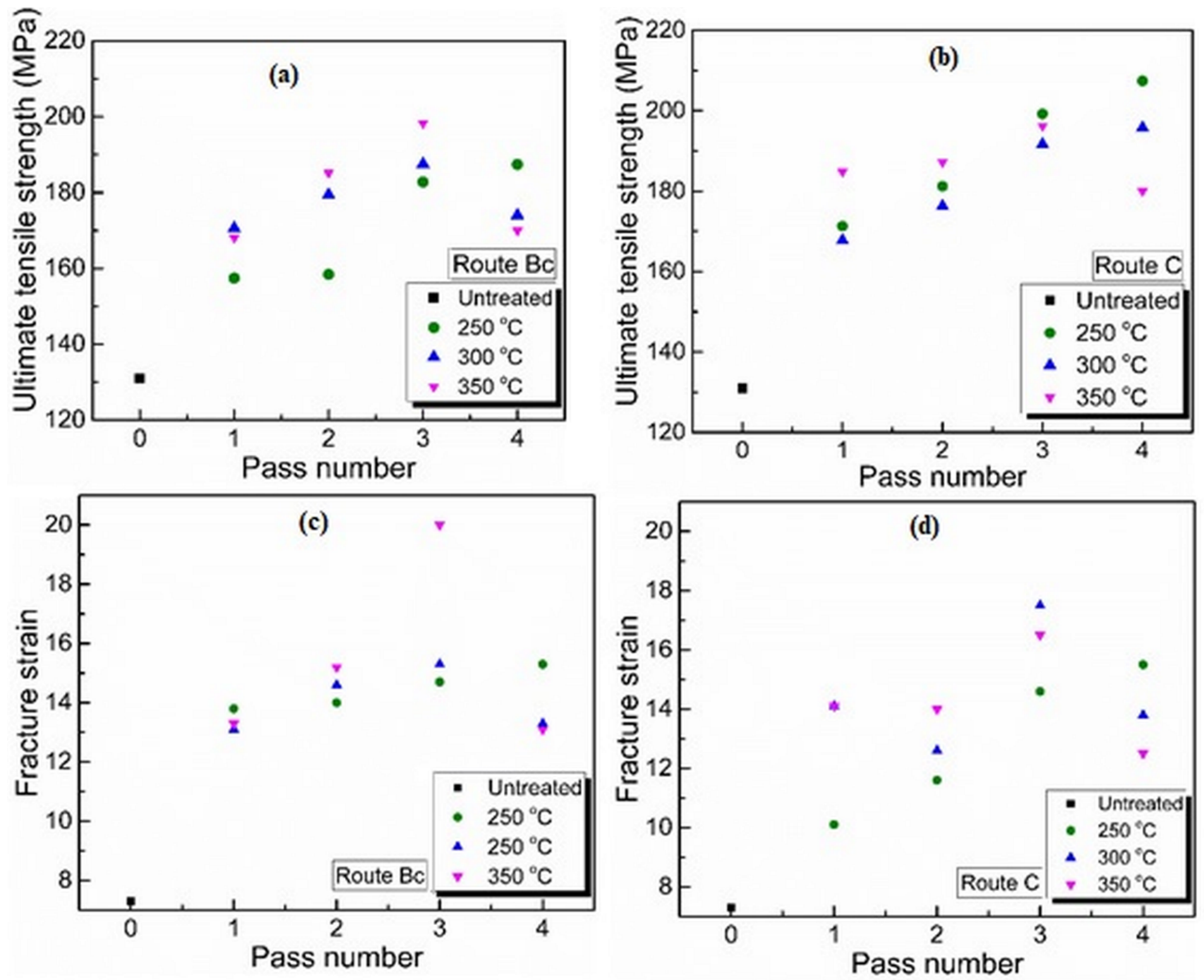

Figure 15

Variation of $(a \& b)$ ultimate tensile strengths and $(c \& d)$ fracture strains of untreated and ECAP samples processed at different temperatures and routes as a function of number of passes. 

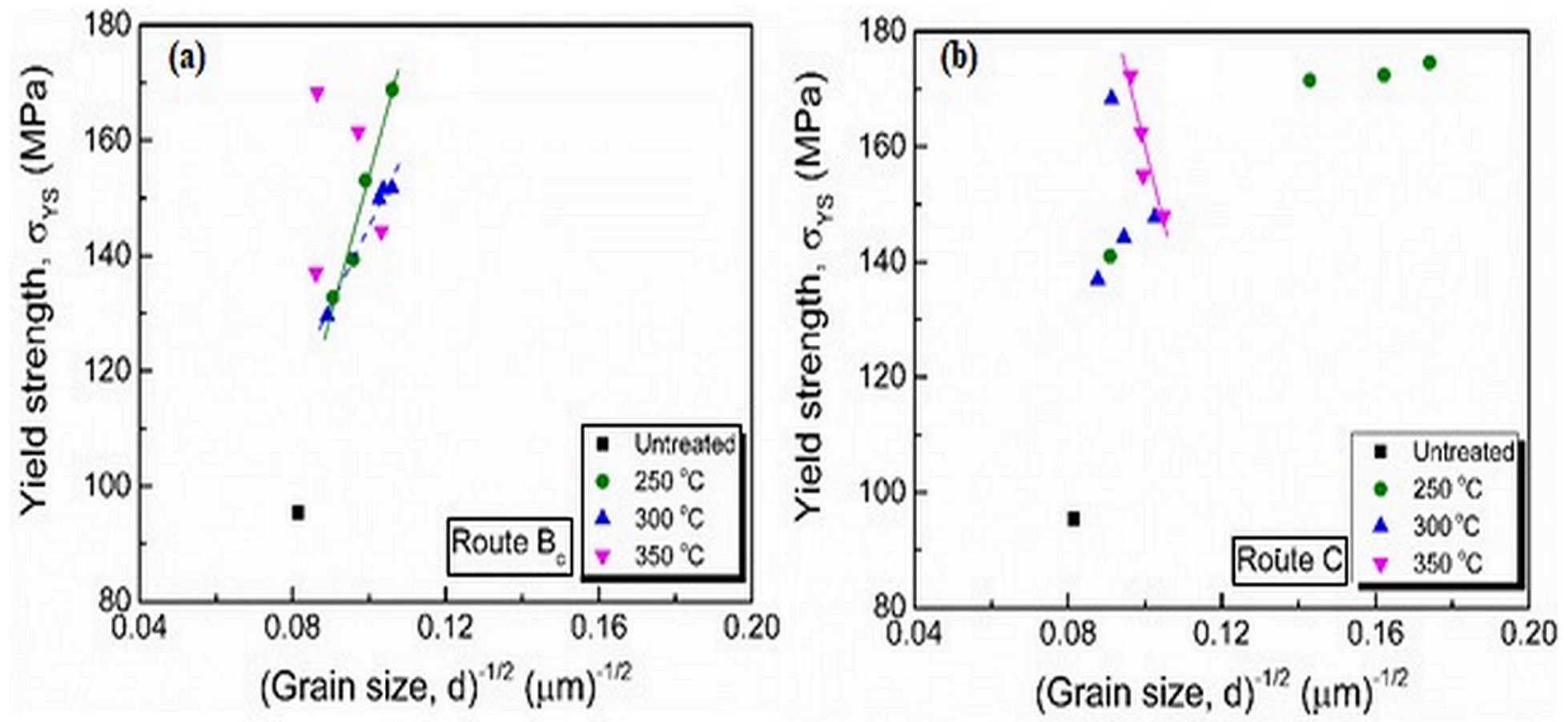

Figure 16

Hall-Petch scaling - yield strength as a function of grain size after each ECAP pass at different temperatures using routes (a) BC and (b) C.
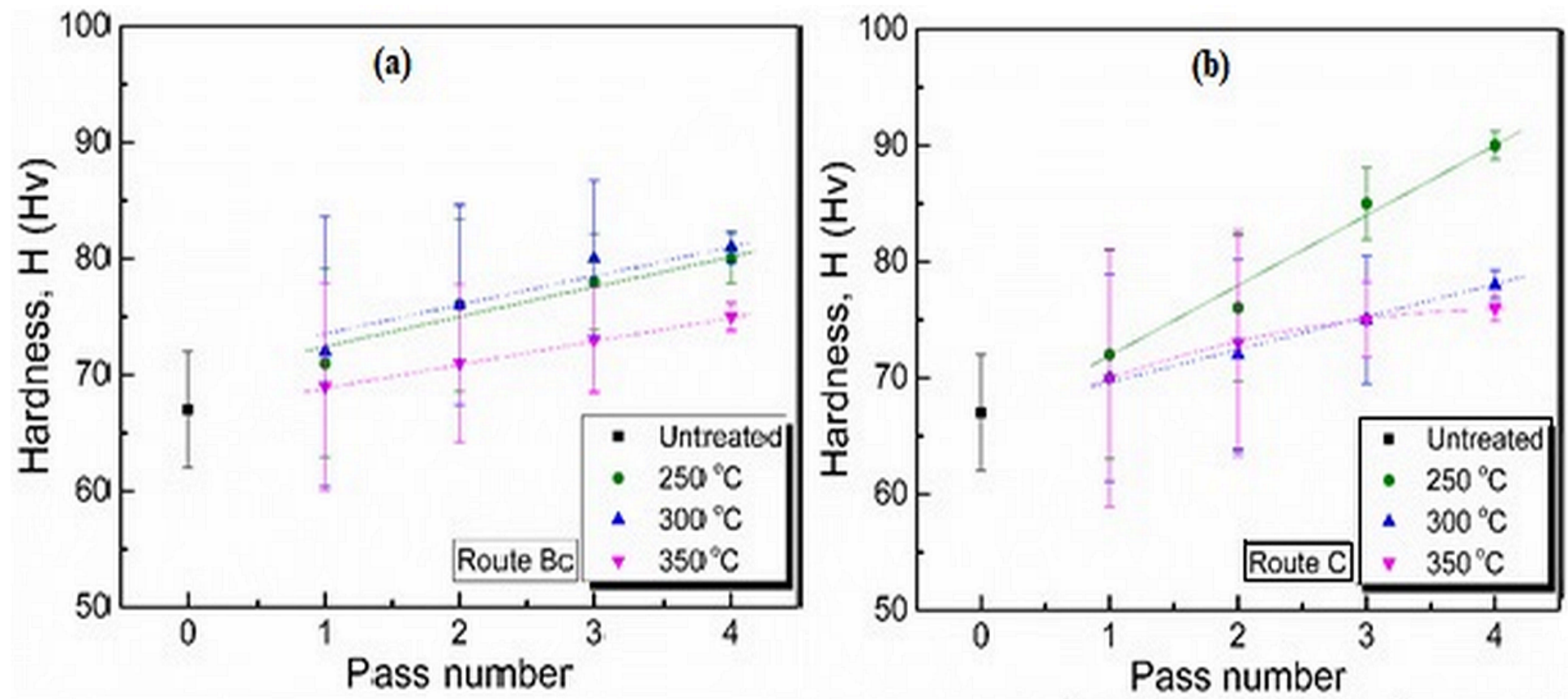

Figure 17

Effect of ECAP passes on the hardness of the ZE41 Mg alloy at different temperatures using routes (a) $\mathrm{BC}$ and (b) $\mathrm{C}$. 

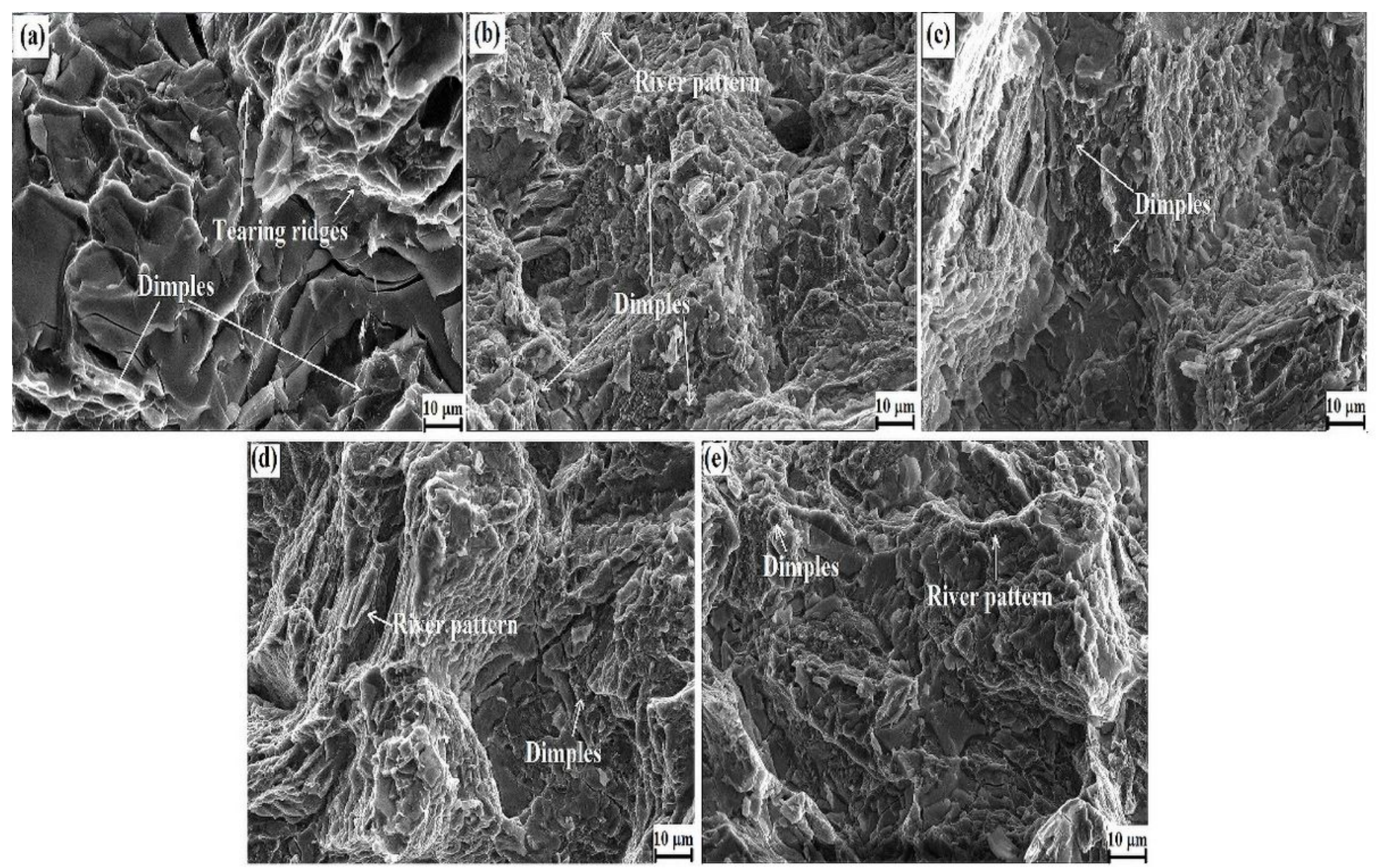

\section{Figure 18}

Fractography of ECAP ZE41 Mg alloy processed at 250 oC using route $C$ (a) untreated (b) 1 pass (c) 2 passes (d) 3 passes (e) 4 passes.

\section{Supplementary Files}

This is a list of supplementary files associated with this preprint. Click to download.

- Supplementarymaterials.docx

- formulas.docx 